\title{
The Dedication Strategies of Conrad Gessner
}

\section{Citation}

Blair, Ann. "The Dedication Strategies of Conrad Gessner." In Professors, Physicians and Practices in the History of Medicine: Essays in Honor of Nancy Siraisi, eds. Gideon Manning and Cynthia Klestinec. New York: Springer, 2017, 169-209.

\section{Permanent link}

http://nrs.harvard.edu/urn-3:HUL.InstRepos:41473908

\section{Terms of Use}

This article was downloaded from Harvard University's DASH repository, and is made available under the terms and conditions applicable to Open Access Policy Articles, as set forth at http:// nrs.harvard.edu/urn-3:HUL.InstRepos:dash.current.terms-of-use\#OAP

\section{Share Your Story}

The Harvard community has made this article openly available.

Please share how this access benefits you. Submit a story.

\section{Accessibility}


For DASH final submitted author's manuscript of :

Ann Blair, "The dedication strategies of Conrad Gessner," in Professors, Physicians and Practices in the History of Medicine: Essays in Honor of Nancy Siraisi, ed. Gideon Manning and Cynthia Klestinec (Cham: Springer, 2017), pp. 169-209

\section{The Dedication Strategies of Conrad Gessner ${ }^{1}$}

The 102 dedications composed by the 16th-century physician and polymath Conrad Gessner between 1541 and 1565 offer a rich trove of insight into many aspects of his particular career but also into the workings of the Republic of Letters more generally. Although Gessner never benefitted from a major patronage relationship and probably received limited financial support from his dedicatees, he nonetheless managed to publish a number of major works on his initiative, including folio volumes of philology, bibliography, and especially expensive works of illustrated natural history. Crucial to Gessner's success was his accumulation of smaller contributions in kind from a wide range of people who offered him hospitality or sent him information and specimens, manuscripts and images, which Gessner used in his publications. Gessner rewarded contributors not only by private expressions of thanks, but also in print, and especially visibly in his dedications. Gessner was also unusual in calling attention to the role of learned printers for his work, by composing dedications to them and by advertising that various of his publications were initiated by requests from printers or bequests of manuscripts by recently deceased scholars. Gessner thus used the high visibility of the printed dedication to invite further contributions from learned readers, bequests of unfinished manuscripts, and proposals from printers with which to fuel his remarkable productivity.

\section{Dedicatio}

Before proceeding I must follow Gessner in making three introductory points which Gessner often made in his dedications and which also apply to this study of mine: praise of the libraries that made this work possible, explanation of the limitations of the work and request for corrections and feedback, and praise of the scholar who inspired the project.

Gessner frequently lauded the owners of great libraries of his day for preserving and allowing him access to rare manuscripts of ancient texts that he prepared for publication. Renaissance libraries funded by the wealthy were a new kind of institution, which Gessner hailed in multiple dedications as crucial to humanist scholarship and to the transmission of knowledge. They housed unique manuscripts but also printed books in rapidly increasing numbers. Similarly, in carrying out this research project I found myself relying on a new kind of library--the collective digital repository of early European printed books that has grown remarkably in recent years. The digital collections in the Swiss E-rara and the Bayerische Staatsbibliothek (BSB), which incorporates part of the 16th-century Fugger collection that Gessner praised, are especially impressive in their scope and quality, but I also drew on Google Books, Gallica, and Hathitrust (as listed in the appendix). ${ }^{2}$ It is more complicated to identify whom to thank for this remarkable collective achievement. Gessner thanked individual owners like Hans Jakob Fugger, Leonard Beck von Beckenstein, and Diego Hurtado de Mendoza, and governing bodies like the City Council of Augsburg for their role in forming and funding great libraries. The formation of our current digital repository has involved 
countless professionals in selecting and managing the books and in making and curating the scans, and private and public organizations in funding the work. I am grateful to them all.

Just as Gessner issued caveats about the quality of the manuscripts from which he worked and the limits of his corrections or improvements, I too must offer some caveats: this study is limited by the copies I used, and I realize that I may not have identified all Gessner's dedications. Digital copies offer no panacea to the complexities of the early modern printed copies that they reproduce. ${ }^{3}$ When the copy used for scanning lacks pages or sections of Gessner's multi-part works or contains manuscript annotations (additions or expurgations), so too does the electronic copy. ${ }^{4}$ As a result it is valuable to view multiple digital copies as well as multiple physical copies, and important to understand the peculiarities of each copy. The copies of Gessner's works from the Zentralbibliothek Zürich are especially interesting in that some of them contain Gessner's own manuscript notes (perhaps made in view of a possible later edition which in most cases did not materialize), but these copies may also represent an early state of production of the book. For example, the printed state of Gessner's Handexemplar of the Bibliotheca Universalis digitized on E-rara is not identical to the copy that served as the basis of the 1966 Olms reprint. ${ }^{5}$ This is not surprising, given what we know about the variation in states of early modern printed books. But we need to remember that a digital copy is no more "representative" of a print run than the single printed copy it reproduces, even if by virtue of being digitized it is more readily available to modern scholars than copies which have not been digitized.

Since Gessner was tirelessly involved in translating, editing, annotating, compiling, and composing, the publication history of his works is particularly voluminous and complex. I have relied on Hans Wellisch's invaluable bibliography and have defined as my corpus the dedications in the works that Wellisch identified as containing Gessner's work which were published during his lifetime. ${ }^{6}$ I searched systematically for dedications only in first editions of these works and included four later editions published in Gessner's lifetime in which I was aware of a new dedication. Given Gessner's propensity to writing many dedications, there may exist other dedications by Gessner that I have not recorded, either in other later editions of his works or in works published by others. Indeed my corpus already brought to my attention one dedication by Gessner of a work composed by someone else: Gessner explained that his friend Benedictus Aretius charged him with finding a dedicatee for the latter's short work on the Bernese Alps which was included in Gessner's edition of Valerius Cordus's annotations on Dioscorides (1561). (Gessner's use of classicized versions of German names--in this case, Aretius for Marti--also complicates the identification of the figures he mentions. ${ }^{9}$ ) I have only considered dedications, which I define as addresses by Gessner to specific individuals or collectivities; these are usually called epistola or epistola nuncupatoria, but occasionally also epistola dedicatoria or (confusingly, given modern parlance) praefatio..$^{10} \mathrm{I}$ have thus excluded Gessner's addresses "to the reader" (lectori, ad lectorem) which he wrote in addition to or occasionally in the absence of a dedication." Gessner's paratexts are well worth further study, but in this context I can only conclude, as Gessner did in one of his dedications, that "due to the shortness of time and other occupations it was not possible to add to [these] descriptions." ${ }^{12}$ I look forward to learning from the corrections and further work of others. 
The scholar who inspired me to investigate this topic has taught us how fruitful it is to study the history of medicine as a branch of general intellectual history rather than a separate sub-discipline. Learned physicians in the Middle Ages and in the Renaissance were trained in philosophy and in the humanistic disciplines (with many variations by context) and brought those skills to their ways of arguing, analyzing, and writing about medical subjects and related fields like the natural history of animals, plants, and minerals. Nancy Siraisi has shown in her most recent books that physicians often wrote on non-medical topics, such as human history, and were active in the Republic of Letters in forming correspondence networks both within but also beyond their professional community. Nancy Siraisi has also brought the history of medicine into the mainstream of intellectual history by making the field accessible to non-specialists through her teaching and her prize-winning textbook --from both of which I benefitted greatly. Like the figures Nancy Siraisi has studied, Conrad Gessner (1516-65) played a crucial role as a learned physician and humanist in his hometown of Zurich and in the Republic of Letters. Medical learning formed a major part of Gessner's polymathy alongside his other interests in philology, bibliography, and Swiss Reformed piety. ${ }^{13}$ Gessner was a master of humanist rhetoric while I am not, so I borrow from one of his dedications for my own: "Receive therefore this little something of a booklet, as a sign of my perpetual admiration for you and a memento of my greatest love." ${ }^{14}$

\section{The several roles of dedications}

The practice of dedicating a work to a powerful and/or wealthy patron can be traced back to ancient Rome, as the humanists knew well. Virgil's dedication of his Georgics to Maecenas inspired the coining of that name to designate a generous patron precisely in the early sixteenth century..$^{15}$ Dedications are generally interpreted as bids for financial support. In the age of print authors made money from selling their manuscript to a printer, or from selling or gifting (in the expectation of a countergift) the printed copies of their works allotted to them by the printer. The sums involved varied depending on the standing of the author. Optimally a dedication would result in further rewards, in the form of a one-time gift of money or other object of value, or an offer of longer-term employment..$^{16}$ The codes of expectations were unwritten and variable by time, place, type of work, and the individual personalities involved, and authors who misevaluated their situation could fail to receive any benefit from their dedication. Gessner's dedications shed light on practices in a particular corner of the Republic of Letters, centered around the Germanic world and focused on learned works of the mid-sixteenth century; especially relevant comparands include the dedications of Erasmus a few decades earlier and those of the Italian natural historian Ulisse Aldrovandi a few decades later.

In this context dedications also served as opportunities to assert authorship. Gessner was often credited in specific ways (e.g. as translator, compiler, editor, author) but sometimes not at all on the title page of the works in his corpus. When Gessner was not named on the title page, his role in the production of the work became visible in the dedication. Conversely, some early modern works were published under the name of a person who either did not compose the work or did not authorize its publication; in these cases the absence of a dedication can serve as supporting (though not in itself sufficient) evidence that the author was not involved in the publication. ${ }^{17}$ In Gessner's corpus $D e$ stirpium nominibus aliquot (1557) contains no dedication since, as the preface explains, the work published an epistolary exchange between Gessner and Melchior Wieland 
without the knowledge of either writer..$^{18}$ Gessner also published two works which he did not acknowledge, at least at first: the Thesaurus Evonymi ... de remediis secretis (1552) which proved very successful, with multiple editions in Latin, English, French, German and Italian, and a Historia et interpretatio prodigii published just once in 1561. Gessner acknowledged both works as his own in his autobibliography, De libris a se editis (1562). He explained there that he hid his authorship of the Thesaurus because he brought the work to print prematurely in order to please the printer, his relative Andreas Gessner who was just setting up his business, but once he realized that the work was well received, he added his name to it. The Thesaurus included a dedication (to Nicolaus ZurKinden, city councilor of Bern), signed pseudonymously by "Evonymus Philiatros"; in 1554 the pseudonym evolved to "Evonymus Gessnerus Philiatros" and by 1558 the title page openly announced Conrad Gessner's authorship. ${ }^{19}$ A pseudonymous dedication seems surprising, since it would not further the author's presumed intention of developing a personal relationship with the dedicatee. But, as others have shown of anonymity, pseudonymity in print was not necessarily strict: without revealing his identity in print the author would remain hidden to a broader readership, while a circle of local contacts might be well aware of the author's identity. ${ }^{20}$ This seems to have been the case with Gessner's Thesaurus from the beginning. Gessner added a handwritten inscription in a copy of the first, fully pseudonymous, edition of Thesaurus to the leading citizen of Zurich, Heinrich Bullinger ${ }^{21}$, indicating that Gessner was happy for his personal contacts to know his identity. It seems likely then that the dedicatee ZurKinden in nearby Bern was also aware of Gessner's authorship. By contrast the 1561 pamphlet describing a wondrous celestial phenomenon contained no dedication; few such pamphlets featured dedications, even when their authorship was explicit. In this case Gessner revealed his authorship only the following year in his autobibliography when he explained that he had withheld his name on the pamphlet lest he be accused of straying "from his last," by writing on a topic outside his usual areas of expertise..$^{22}$

The impact of printing on dedication practices awaits thorough study. Certainly dedications of literary works were common in the Middle Ages and served similar purposes of asserting authorship and seeking patronage. ${ }^{23}$ But we can surmise that printing raised the stakes of the dedication by disseminating more widely and unpredictably that public expression of a personal relationship, which lay at the core of the genre. It is clear that dedications and front matter became more common and more voluminous in printed works than they had been in medieval or humanist manuscripts. Niccolò Perotti gives us one indication of this increase when he noted with disapproval in 1470 that editors of classical texts added prose of their own (in dedications and prefaces) which was unworthy of being printed alongside the ancient works. Perotti reported that he erased or cut out these offending passages in the books he owned. ${ }^{24}$ Despite such disapproval, the inclusion of paratexts in humanist editions became the norm. The prolific Erasmus set a powerful precedent in composing over 150 dedications in the best humanist Latin during a career which spanned 221 publications (counting first editions only). ${ }^{25}$ Early in his career, when he pieced together income from many different sources, Erasmus sought to reach as many potential donors as possible, by composing separate dedications to different people for the various "books" within a single printed work, and by sending inscribed copies of his books to important people in the hope of payment. In exchange for dedications in print and for gifting copies of his books with manuscript inscriptions 
Erasmus often received money or valuable goods--including silver cups and vases (including one filled with coins, another with rare fruit), and horses. He could either sell the gifts for monetary gain or enjoy them as a sign of his relations with the wealthy and powerful. ${ }^{26}$ Nevertheless in surveying the more than 150 dedicatees to whom Erasmus addressed his works, Jean Hoyoux saw no overarching strategy: "students, bishops, kings, and simple humanists intersect [on this list] without order, according to his whim. ${ }^{27} \mathrm{By}$ 1540 when Conrad Gessner started his publishing career, he could draw for inspiration in his dedication practices on the great prince of humanists who spent the most glorious years of his career in nearby Basel-- Erasmus died there in 1536, when Gessner was 20 years old.

\section{Gessner, the abundant dedicator}

Even compared to Erasmus, Gessner took dedicating to new heights. Although he published many fewer books, Gessner reached just as many dedicatees, outfitting all but eleven of his publications with at least one and often more than one dedication. Fiftyseven works of Gessner's contained 102 dedications addressed to a total of 127 individuals and 6 collective bodies (city councils and university faculties). Almost half of the works with dedications were addressed to more than one person, either through a single dedication addressed to multiple people, or through multiple dedications within one work, or a combination of both. ${ }^{28}$ Sometimes Gessner took advantage of the different parts of a single coherent work to compose many dedications, as in the Pandectae (1548) with 19 dedications, or De piscibus (1556) and Nomenclator piscium (1560) with four each..$^{29}$ In other cases the publication was an anthology of multiple works, inviting a dedication for each. When Gessner edited the various manuscripts of the recently deceased scholar Valerius Cordus, he added three other texts (two of his own and one by a friend) and composed ten dedications for the multiple parts that resulted. When Gessner was one of multiple authors/editors/translators involved in one publication, each composed a dedication for the section containing his work, so that the dedications by Gessner which I list in the appendix may constitute only a subset of the dedications present in that work. ${ }^{30}$ No doubt first dedications were more prestigious; they were more visible to the casual user of the book and were often longer. Gessner's longest dedications were all first dedications; they operated as mini-treatises extolling the significance of the topic. One of these, in one of Gessner's earliest works, De lacte (1541), has become famous as a separate text for its celebration of the beauty and utility of the Alps at a time when mountains were generally viewed only in a negative light. ${ }^{31}$ Conversely, some of Gessner's "internal dedications" positioned later in the work were remarkably short. ${ }^{3}$

Gessner's editions of Greek texts with Latin translations offered opportunities for separate dedications for the text in two languages. In three of these cases Gessner composed dedications in Greek to accompany the Greek text he edited--this was a rare feat which even Erasmus did not attempt. Gessner published his Greek dedications late in his career in his editions of 1559 (editio princeps of Marcus Aurelius, De vita sua), 1562 (Cassius, Naturales et medicinales quaestiones) and 1565 (Dioscorides, De curationibus $){ }^{33} \mathrm{He}$ addressed the first to the nobleman Anton von Werther of Beichlingen, referring to the latter's recent visit to Zurich, and the other two to people he knew well: his former student Antonius Schneeberger, who had become a physician in Cracow, and the imperial physician and frequent correspondent Johannes Crato von Krafftheim, respectively. Gessner's Greek dedications followed the mold of his Latin 
ones, including praise of the dedicatee and reminiscences of his contact with him, and in the edition of Marcus Aurelius (as in the longer Latin dedications) a mini-treatise relevant to the text being published--to wit, a defense of the merits of studying a pagan work when it is morally edifying. These Greek dedications called attention to the exceptional skills of both their writer and their recipients, who were presumed able to read them, and they would dazzle those more ordinary readers who could not.

As Hoyoux remarked of Erasmus's dedicatees, Gessner's also spanned a wide range of people. No doubt contingent circumstances we cannot recover played a role in many choices of dedicatee. Nonetheless we can recognize the broad arc of Gessner's career through these choices. During the 1540s Gessner first addressed teachers and fellow students from his early years, then turned to colleagues and friends, and finally to city officials responsible for the first stipends and appointments he received. After a few years of teaching Gessner also selected students of his own as dedicatees, starting with the 1549 edition of his Onomasticon or dictionary of proper names dedicated to eleven young Zurich patricians, whom he had presumably taught, reminding them that "philosophy is a divine good" and that they should be an ornament to their city. He offered the dedication (dated from the first of January) as a new year's gift, observing that "you'll enjoy its dedication to your names." ${ }^{34}$ At midcareer, after his first major works (Stobaeus in 1543, the Bibliotheca and Pandectae of 1545 and 1548) had broadened his reputation beyond the greater Zurich area, Gessner became more ambitious, addressing some of the most powerful figures of his time, especially in his expensive illustrated works of 1551-58. Gessner also diversified his bids for patronage by addressing collective bodies, both local (Zurich and Basel) and less so (Wittenberg and Augsburg). At the same time throughout his career Gessner regularly wrote dedications, for his lesser works or in "internal dedications" to separate parts within a work, to people like him engaged in medical and learned scholarship-- 25 doctors, 5 apothecaries, 5 churchmen, 4 lawyers, and 8 professors, accounting for more than one third of his dedicatees. Typically Gessner had corresponded with and/or met them, and Gessner thanked them for contributing to his projects by providing access to manuscripts, books, people, or information. In other cases Gessner used the dedication to pressure them publicly to send him materials, notably from their far-flung locations, such as images of birds from England or of fish from the Baltic. ${ }^{35}$ In the last six years of his life Gessner no longer sought patronage from the great and powerful and instead used his dedications to cultivate relations with scholars and in one case writing a dedication on behalf of the orphans of a deceased author.

\section{Gessner's bids for major patronage}

Gessner followed what was likely a common pattern at the time of dedicating his major works (i.e. the expensive folio volumes with or without illustrations) to the most socially prominent among his dedicatees. ${ }^{36}$ These included city officials addressed individually or collectively. Gessner dedicated to two senators from Bern whom he thanked for his stipend to study in Lausanne, his first folio volume, Stobaeus's Sententiae of 1543. In his Bibliotheca of 1545 Gessner called that work the most useful thing he had published to date; although Gessner is far better known today for his Bibliotheca, it never reprinted, whereas Gessner's editio princeps of Stobaeus was the basis of a further 15 editions down to $1838 .{ }^{37}$ Gessner addressed the first two volumes of his Historia animalium to the City Council of Zurich (1551) and to senators from Fribourg and Bern 
(1554) respectively, and reached higher for volumes three and four, dedicated to Johann Jakob Fugger (in 1555) and the emperor himself (in 1558).

Gessner approached only two grandees more than once. Gessner first addressed Leonhard Beck von Beckenstein, counselor to the emperor Charles V, with a dedication of February 1545 to his edition of manuscripts of Telesio. ${ }^{38}$ This fulsome 6-page dedication was devoted almost entirely to praising the dedicatee, his virtues which made him many friends, his frugal life and love of learning, and his great library. In return Gessner promised him the immortality of literature: "from the inscription, Leonhard, you will have like an inseparable link from your name to posterity. In part since these books are small and unworthy of your amplitude; in part because they will become more illustrious from the splendor of your virtue." ${ }^{{ }^{9} 9}$ The response Gessner received was presumably encouraging because just five months later Gessner also dedicated to Beck von Beckenstein his most important work to date, the Bibliotheca universalis of 1545, an alphabetically arranged bibliography which aimed to include all known works in Latin, Greek, and Hebrew. Gessner devoted much of this long dedication to a "mini-treatise" on the significance of libraries and his own motives and labors in composing the Bibliotheca. His most explicit plea for funding (with a pointed criticism of the tightfistedness of the wealthy of his era) appeared buried in the text, in the entry for himself where he listed his own works published and in progress. There he explained his plan: to write a complete history of animals, with their names in various languages, and images.... If some generous Maecenas would manifest himself and support the project, this whole history will be made more perfect. If not (since now many rich people are avaricious and live for themselves and not for good studies) I will not cease to pursue this laudable topic as my strength allows. ${ }^{40}$

Gessner had already praised von Beckenstein as one who knew how to spend his wealth well in his first dedication to him: "It's most difficult in fact and achieved by very few [to spend wealth to benefit others]. ... Your glory comes in no small part from ... your frugal life, embrace of good letters ... and promotion of the studies of wisdom." ${ }^{41}$ In the Bibliotheca Gessner also emphasized von Beckenstein's devotion to building a great library and followed the dedication with a lavish full-page engraving of the latter's coat of arms (which was hand colored in the copy at the ZB Zurich) ${ }_{{ }^{42}}$ This was a clear bid for patronage, complete with allusions to the great patrons from antiquity. But Gessner must have been disappointed. He praised von Beckenstein as his "maecenas and patron" in a preface in 1548 but then addressed him just once more, seven years after that, dashing off a 9-line dedication on a fold-out table of the Lord's prayer in different languages appended to his Mithridates (1555) in which he treated him as a potential expert contributor, inviting him to send corrections or examples in old German to his discussion of the diversity of languages. ${ }^{43}$

For his next work after the Bibliotheca, in February 1546, Gessner turned instead to the wealthiest man of his day, Johann Jakob Fugger, renowned for his great library and patronage of arts and letters. In summer 1544 Gessner had travelled to Augsburg at Fugger's invitation where he was offered a well-paid post with access to the library and duties tutoring Fugger's children. ${ }^{4}$ Gessner declined the position, which would have required moving to Catholic Augsburg and entering into a classic client-patron relationship. Gessner never articulated his reasoning but historians have emphasized Gessner's commitment to Zurich and its religion. Nevertheless Gessner continued to 
cultivate the relationship. Gessner's Greek and Latin editions of the Sententiae of the 11 and $7^{\mathrm{H}-\mathrm{c} e n t u r y}$ monks Antonius and Maximus published in two separate volumes in 1546 sported two major dedications and one less visible one inside the Latin volume, all of them building his connections with Augsburg. The Greek edition was dedicated to "Johann Welser and Jakob Herbrot and the whole most prudent Senate of Augsburg" who were praised for the recently formed library in Augsburg which "had no match in all Germany" : "whereas in most collections ... most books are vulgar and useless, in the Augsburg library all the books are rare." Gessner had in mind especially the remarkable collection of very old Greek manuscripts there. Gessner also stated very clearly what he hoped for in return: "I dedicate it ... to you, so that I will enjoy the occasion to conveniently request some books from your library"--a wish that was granted probably more than once. ${ }^{45}$ The Latin volume Gessner dedicated to Johann Jakob Fugger with the requisite praise and also a very explicit bid for financial support: "if you like this work you could add encouragement so that I can proceed faster with the Historia animalium with pictures." ${ }^{\prime 6}$ It is doubtful that the plea to Fugger was effective, since Gessner did not dedicate a volume of the Historia animalium to Fugger until nine years later. Gessner noted then, as if apologizing for the delay, that he had "already many years ago formed the plan of dedicating to you." Gessner praised Fugger's generosity and learning in rather general terms, invoking the testimony of his librarian Hieronymus Wolf and especially his LIBRARY (mentioned in capital letters to highlight it), which rivalled that of many kings and from which Gessner no doubt hoped to gain access to more manuscripts. ${ }^{47}$

In 1555 Gessner also approached Johann Jakob's younger brother Ulrich Fugger with his Icones avium, perhaps hoping to leverage sibling rivalry to entice one or both Fuggers to be generous at the same time. It is not clear if they were. In 1556 Gessner again chose Johann Jakob as dedicatee, whom he addressed as "his lord and maecenas," for his Greek and Latin edition of the works of Aelian. But this dedication was clearly couched as a thank you not for funding but for the loan of books --the "oldest Greek manuscript" of Aelian from the library of the city of Augsburg and a further manuscript from Fugger's own collection, which formed the basis for Gessner's edition. ${ }^{48}$ The favor was not inconsiderable, since the manuscripts were presumably sent to Zurich for Gessner to work from. In return Gessner hoped that Fugger would add his new edition of Aelian, "complete, corrected, bilingual" and printed, to the famous library in Augsburg. ${ }^{99}$ But Gessner also broached his hope for a gift of money by mentioning that "within our memory François king of France received Aelian's books on animals given in Latin by Petrus Gillius with a grateful and generous mind." ${ }^{\text {so }}$ Comparing Fugger the merchant to the king of France was a kind of flattery, which invited Fugger to imitate royal largesse. We can surmise that Gessner's bid was not successful, though, since Gessner did not make any dedications to the Fuggers among the nineteen further books he published before his death in 1565 .

Once Gessner declined Fugger's invitation to join the latter's "court" and become a full-fledged client, it is perhaps not surprising that Fugger never became a steady patron to Gessner. Gessner shifted to a strategy of cultivating a variety of learned men in Augsburg, which after Zurich is the single best represented place among the locations of his dedicatees. Starting in 1555 Gessner selected a number of Augsburgers as dedicatees-all of them physicians: Geryon Seiler (1555 Chirurgia) who had drawn Fugger's attention to Gessner twelve years earlier, Laurentius Gryll (1555 De raris herbis) whose 
education was funded by Johann Jakob Fugger, Achille Gasser (1555 Enchiridion rei medicae) and Ioannes Crato von Krafftheim (1565 edition of Dioscorides), both longstanding friends and correspondents, and Adolphus Occo (1565 De omni rerum fossilium genere) whom Gessner asked to check a point of scholarship in a manuscript of the Bibliotheca of Photius in the Augsburg library.." In the 1546 Sententiae Antonii et Maximi Gessner issued the first of a few characteristic "group greetings." Deep in the volume Gessner added a translation of an oration by Tatianus, which was the occasion for a short dedication to Georgius Laetus, rector of the Gymnasium of Augsburg. Gessner thanked him for his hospitality (presumably during his trip of 1544) and asked Laetus to convey greetings from multiple figures in Zurich to multiple figures in Augsburg: "Other learned men here greet you, especially Heinrich Bullinger, Rodolph Gwalther, our church bishops and our Ioannes Frisius. And from me please say hello to Wolfgang Musculus, Michael Cellarius, Bernardinus Ochinus Senensis [the father of 1565 dedicatee Adolphus Occo], Ioannes Heinrich Helt and Xystus Betulaieus, men whom I love dearly." ${ }^{s_{2}}$ This greeting appeared in a P.S., positioned after the usual dated sign-off, as it might have appeared in a manuscript letter. While early modern dedicatory epistles may often seem to be letters in name only, Gessner used several dedications as a way of conveying news from one place to another, as one would in a manuscript letter, though print would disseminate them more widely and impersonally. Gessner sent greetings in this way, also on behalf of others in Zurich including Heinrich Bullinger, to English friends who had recently returned to England from their Marian exile in Zurich (in Icones avium 1560), to friends in Rhaetia/Graubünden (Ars magirica 1563), and to learned men in Danzig (De halosantho in De omni rerum fossilium genere 1565).

The advantage for Gessner of not having entered a relationship of clientelism, e.g. with Johann Jakob Fugger, is that he could try his luck in addressing those even further up the social hierarchy. Gessner chose dedicatees most ambitiously for the slim folio volumes that reprinted the expensive illustrations of the Historia animalium without the bulky scholarly text. These volumes entitled Icones were crucial money-makers by which the printers hoped to recoup the vast expense of making the illustrations..$^{53}$ They also seemed appropriate for the highest-ranking dedicatees who likely were given handcolored copies. ${ }^{54}$ Gessner dedicated the first of these volumes, the 1553 Icones animalium, to Thomas and John Grey, brothers of Henry Grey Duke of Suffolk; the dedication was ill fated in that Henry and Thomas were executed a few months later on suspicion of treason under Queen Mary. In 1555 Gessner dedicated the second such volume to Ulrich Fugger.

Gessner and Froschauer, who printed the Historia animalium and associated other volumes, gave themselves a further opportunity for income from these images by publishing a second edition of each of these Icones in 1560. In June of that year Gessner addressed the second Icones animalium to Elizabeth I who had recently acceded to the throne of England, and demoted the original dedication to the Grey brothers as an internal dedication to the newly added second part of the book. Gessner's dedication to Elizabeth is the one clear case of a failure. Although Gessner composed a fulsome three-and-a halfpage dedication topped with a 28-line ode in Greek to Elizabeth (which was perhaps his first published composition in Greek), Elizabeth did not appreciate his explanation in the opening line that he addressed her since the dedicatees of the first edition had been killed in the interim, as if she were some kind of second choice. Apprised of the Queen's displeasure, Gessner wrote a letter to William Cecil, Elizabeth's chief adviser at the time, 
which is recorded in the Calendar of State papers for March 1561. Gessner explained "that he ha[d] never received a farthing from any one" of the Greys as a result of that dedication, though he heard that the relations of the deceased were not displeased with it. Gessner also pleaded poverty ("having forty needy relatives") and requested that "the price of the books sent (amounting to four crowns) be transmitted to him." He enclosed another recent publication and requested that Cecil reply through his closest English friend, John Caius, a physician to whom Gessner had recently dedicated a part of his 1556 De piscibus. A payment of 6 pounds to Gessner was recorded a few months later, presumably for his expenses-- a far cry from the reward he must have hoped for. ${ }^{55} \mathrm{~A}$ month after his dedication to Elizabeth and unaware of its unfortunate reception, Gessner directed the second edition of the Icones on birds to another English contact, John Parkhurst, who had spent Mary's reign in exile in Zurich and had recently been named bishop of Norwich on his return after Elizabeth's accession. Gessner had praised Parkhurst in his dedication to Elizabeth for encouraging him to approach the queen, so in this dedication to Parkhurst Gessner offered a thank you for serving as a broker to the queen (though Gessner learned later it was ineffective), alongside a request to send more images of English birds gathered from learned Englishmen. Printed dedications preserve for readers far away in time and space only the happy words of praise and hope, not the unhappy aftermath which ensued in this particular case in manuscript letters and archives and face-to-face interactions that we can reconstruct only partially.

Gessner was more successful closer to home. In 1558 Gessner dedicated the fourth volume of his Historia Animalium to the newly appointed emperor Ferdinand I, calling attention to his "labors which were immense, not to mention the expenses." Gessner also pointed out that he "had so far no patron or maecenas," and argued that he was "more worthy of pardon if I do not satisfy expectation" as a result. ${ }^{56}$ The emperor responded by inviting Gessner to Augsburg during a Reichstag and awarding him noble status and a coat of arms; these were even authorized for transmission to a lateral relative (as Gessner had no children). . $^{57}$ That transfer took place after Ferdinand's death under the new emperor, Ferdinand's son Maximilian II. Gessner had also dedicated a work to Maximilian when the latter was king of Bohemia and archduke of Austria-- the third and last of the Icones volumes, on fish, published in just one edition in 1560. With all these highest-ranking dedicatees Gessner relied on intermediaries to facilitate the dedication, whom he names (just he had named Parkhurst as his contact to Elizabeth). In the case of Ferdinand these were the imperial "learned doctors Iulius Alexandrinus and Stephanus Lauraeus of Amersfoort [Netherlands]" who both received dedications of their own, though only internal dedications..$^{58}$ Gessner dedicated to Alexandrinus a short De anima of his own composition which appeared in his 1563 edition of Valentinus's De Anima, and to Lauraeus an extensive catalog of German gardens appended to his 1561 edition of Valerius Cordus's notes on Dioscorides. In both these dedications Gessner recalled his visit to Augsburg and the presence of the dedicatee when he spoke to the emperor or dined with "the illustrious J. J. Fugger." ${ }^{\text {s9 }}$ In his dedication to Maximilian, Gessner explained that he was "emboldened" to approach the king by Paul Scalichius, of very ancient noble family, and the most learned Ioannes Sambucus, though neither of them received a dedication from Gessner ${ }^{60}$

The role of these brokers was crucial. Through personal access to the dedicatee the broker could ascertain the interest of the ruler in receiving a dedication. And once the 
book was finished, if the author lived far away, intermediaries again intervened in presenting the book to the ruler. Skill was required to maximize success by making the presentation under optimal circumstances, e.g. when the dedicatee was in a good mood and well disposed to receive it with pleasure and generosity. ${ }^{61}$ Gessner cultivated a number of professionals in the ambit of the emperor, not only as intermediaries but also as potential patrons in their own right. He naturally knew the doctors best, and they could also contribute to his projects from their expertise. In addition to Alexandrinus and Lauraeus, Johannes Backofen von Echt (Echtius) was another imperial physician whom Gessner thanked with a dedication, for contributing images of fish (in his Xenocrates de alimento ex aquatilibus, 1559). ${ }^{62}$ In his early years when he was casting about for a patron Gessner made his clearest bids to imperial counselors: not only Beck von Beckenstein, but also Caspar von Niedbruck, the dedicatee of his 1555 Appendix to the Bibliotheca to whom he wrote bluntly: "I very much want to be among your clients." ${ }_{63}$

Gessner approached another major player in the imperial ambit in his 1545 Lexicon Graecolatinum: Diego Hurtado de Mendoza, a Spanish diplomat who served as imperial ambassador to Venice and took advantage of his location to form a great library of rare Greek manuscripts which he purchased or had copied. The first edition of this dictionary in 1537 had made neither mention nor much use of the many additions and corrections which Gessner had given the printer, as Gessner complained in his autobibliographies ${ }^{64}$ But in this fourth edition of 1545 , Gessner was clearly positioned as the author on the title page and in the dedication (which, unusually, was also mentioned on the title page). In praising Mendoza and his library Gessner seemed eager to elicit more information on this rather secret scholarly resource when he wrote: "once the learned Arnoldus Arlenius Peraxylus showed me the catalog of your Greek collection. ... The greater part of the learned will soon know that remarkable books are hiding in your library when they read mention of them in our Bibliotheca, which I have just completed, since your name is cited every time that I knew you owned rare Greek books." "6s Gessner also listed Mendoza's library catalog among the major sources of information for his Bibliotheca universalis. ${ }^{6}$ But it is not clear whether the dedicatee appreciated the publicity-- I have found no further mention of Mendoza in Gessner's corpus. Mendoza's library became the property of the king of Spain at his death in $1575 .{ }^{6}$

Very little evidence survives of Gessner's finances, so the pattern and language of his publications and dedications--whom he approached when and whether more than once--is often the best evidence we have about their impacts, though it is only suggestive. Gessner was clearly much less successful in eliciting income than Erasmus, who lived well from his publications (including payments from printers, countergifts for dedications, and sales of his books). But Erasmus was such a best-selling author that printers and dedicatees sought him out instead of the reverse. Gessner never approached the level of renown of Erasmus and did not enjoy many years at the height of his reputation, whether we date that height to 1555 --Gessner's annus mirabilis in which he published seven books and a woodcut portrait was first made of him-- or to 1558 which brought his ennoblement and (from an unrelated source) greater financial security ${ }^{68}$ Gessner's straitened finances had long been a source of concern: he worked for the city of Zurich as physician and teacher and complained of being poorly paid. Gessner taught small children in his first year of teaching in Zurich then obtained an appointment at the Carolinum teaching adolescents in 1546. To increase his income Gessner took on a great 
many editing tasks for publishers in Zurich and Basel who paid him for his work and thus encouraged his prolific output. ${ }^{69}$ But Gessner probably did not make much money from his dedications; if he had, given that he wrote so many of them, he would have been a wealthy man. Gessner moved from one dedicatee to the next, at first searching for a patron, then in his later years having seemingly abandoned the hope or the desire to identify a major donor. In 1558 Gessner composed a letter to Heinrich Bullinger appealing for greater support from the city officials, citing the toll that his relentless rhythm of work was taking on his health. An appointment as cathedral canon that resulted "eased his financial situation somewhat," but just seven years before his death. ${ }^{70}$

Gessner used the term "patron" in a handful of cases, as a term synonymous with dedicatee (e.g. "lest this book arrive imperfect without a patron into the hands of men") whose role was to protect and judge the work. ${ }^{11}$ Gessner applied the term consistently and in more heartfelt language to one person in particular, Heinrich Bullinger (1504-75), intellectual and ecclesiastical heir to the Zurich reformer Ulrich Zwingli and, as leader of the city council, the person most responsible for Gessner's employment. Gessner dedicated two works to Bullinger, his edition of Martial's epigrams in 1544 and his edition of Greek theological works in 1557 . We also have the copy that Gessner inscribed to Bullinger of his 1552 Evonymi Thesaurus: "to his dearest patron, Conrad Gessner." Gessner addressed Bullinger alongside other city officials in 1544, articulating the hope that they would assign Gessner's expurgated edition of Martial in the schools. ${ }^{73}$ In 1557, the year before Gessner wrote his letter requesting better financial support, Gessner showed great respect in addressing Bullinger as his "patron and judge (vindex)" asking him for corrections as needed on matters of Greek or of theology --Gessner was thus expressing in advance his willingness to conform to any censure of his interpretations by the chief theologian of Zurich ${ }^{74}$ Gessner wrote with special self-consciousness about Bullinger's generosity: "Long since I should have given you some evidence of my gratitude and memory of your benevolence because of many great kindness to me (beneficia): although your generosity does not require it." ${ }^{75}$ Gessner seemed to attempt to forestall the notion that this dedication was born of Gessner's frustration with the level of generosity Bullinger had displayed recently, although such frustration is perhaps exactly what had motivated it.

Dedications to collective bodies were less common than dedications to individuals, but not unique to Gessner. ${ }^{76}$ Gessner's six dedications to collective bodies resulted in the one gift he received that has so far been documented (thanks in part to the record-keeping of such bodies). Gessner dedicated the first volume of the Historia animalium to the City council of Zurich in 1551, which voted (likely under Bullinger's leadership) to award him an annual allotment of 10 Malters of grain (rye or wheat) and 10 Eimer of wine (presumably for his lifetime). ${ }^{77}$ For his 1561 posthumous edition of works of Valerius Cordus Gessner chose "the most excellent of patrons, indeed the whole medical college of the university of Wittenberg. ${ }^{178}$ Collective bodies ranked behind but not far behind the greatest individuals, judging from the order of dedication in Gessner's Icones on fish of 1560: the lead dedication was addressed to King Maxmilian; the next, for the book on fresh water fish, to the city council of Basel ("I thought of you first as patron because your famous city is founded on the Rhine, the greatest river in Europe..."); a third dedication was addressed to the imperial diplomat Sigismund of Herberstein, and a fourth, short dedication to a fellow doctor and author, Levinus Lemnius. ${ }^{79}$ Gessner 
recalled his dedication to the Basel city council when dedicating two years later his edition of Galen's Opera to another Basel collectivity, the professors of the University, who awarded him 5 Taler.$^{80}$ Gessner approached Augsburg a second time in 1565 in an edition of Dioscorides's De curiationibus. This was a Latin translation of a Greek manuscript found in the Augsburg library which Johann Moibanus had started but left unfinished at his death, entrusting it to Gessner to see it through publication. Gessner's dedication was entirely pitched as a plea for support for Moibanus's children who had also lost their mother and were orphaned. ${ }^{81}$

\section{Gessner as booster of learned printers}

Printers played a significant role in Gessner's finances and career. They were mentioned remarkably frequently in Gessner's dedications, and even appeared as dedicatees themselves. In 1548 Gessner experimented with the power of the dedication in an unusual way in his Pandectae, which offered a thematic index to the learned literature he had inventoried in his Bibliotheca Univeralis of 1545. Gessner divided the Pandectae into 19 books, each corresponding to a field of study and for each of which he composed a dedication to a different learned printer of his day. He extended the pattern in a separate volume on theology in 1549 , but never completed the projected volume on medicine. Gessner explained that the order of the dedications was based not on any judgment of relative merit, but on "their argument" ---that is, he selected for each book of the Pandectae a printer who had excelled in the area treated in that book..$^{82}$ Gessner explained that his purpose in these dedications was "to incite the [printers] to continued diligence in learned publications." ${ }^{{ }_{83}}$ Gessner offered each of them praise of the kind usually extended to more socially prominent dedicatees and in many cases he publicized their activity by listing many or all of their publications following the dedication. While many scholars criticized printers for their errors, haste, or indifference to learning, Gessner viewed learned printers as a crucial resource for the transmission of knowledge, who should be honored and supported.

In his letter of appeal to Bullinger in 1558 Gessner also revealed how commissions from printers were an important source of income when he explained the decisions he faced just then:

Frobenius (the bookseller) in Basel demands that I compare for him the Latin translation of Galen's complete works with the Greek original text (a work that demands an immeasurable amount of labour), and I have to give him my decision within a month. Froschauer (the famous printer in Zurich) asks me to make for him an excerpt from my three large volumes of the natural history of animals. Exhausted from so many exertions, emaciated, enfeebled, half blind and sometimes not quite conscious of myself (how could it be otherwise, since I am forced to write so many, variegated, and wide-ranging works), I shall now again take this yoke upon me, shall again take on a work that would not let me breathe freely for two or three full years. Would you, my friend, advise me to do this? ? $^{84}$ Gessner suggested that he would not take on such onerous tasks if he did not need the income they generated. Indeed it appears that Gessner did not engage in the hard work of collating Galen once his letter had resulted in an improvement of his income from the city. In 1559-60 an account book from the Froben-Episcopius printing house recorded a payment of somewhat more than 15 pounds to one Elias Philippinus for doing that work. In fact Gessner became involved two years later with this same edition of Galen but in 
the more glamorous role of writing a preface for which he was paid 15 pounds in 1562 by Froben and another 15 pounds for unspecified purposes by Episcopius (perhaps his fee of 30 pounds was split between the two printers). ${ }^{85}$ This was a tidy sum, given that early in his career Gessner earned roughly half that amount (30 florins) in a whole year and we know that Heinrich Bullinger, who outranked Gessner in the city hierarchy, was paid one pound per 6 folio pages he wrote ${ }^{86}$ Gessner's preface to the Galen edition was no simple affair, but a 73-page bio-bibliography of Galen, including the fortuna of his works down to Gessner's time ${ }^{87}$ In the dedication of that work to Basil Amerbach and the faculty of the University of Basel Gessner explained: "since the printers, from whom I am conscious of many great benefits toward me, decided that I provide prefaces, despite my weakness I couldn't dare refuse them." ${ }^{88}$ The appearance of the modesty trope may in fact result from Gessner's awareness of having been paid an unusually good fee in this case for his writerly services.

Of course Gessner's unremitting editorial work was not motivated exclusively by financial need. Throughout his life Gessner worked to promote the transmission and growth of knowledge through high quality editions of ancient and modern texts. But the specific ways in which Gessner did so were often the result of printers asking him for something to publish, or other scholars entrusting him with texts to publish. These themes surface especially in the dedications of his later years (e.g. after 1559). For example when his relative Andreas Gessner was preparing an edition of Leo Africanus's Description of Africa in 1559 and asked him for "something new to add to it, since my leisure was not suited to greater things, I thought of translating" a short text by Hanno of Carthage (5th century) describing an expedition on the Libyan coast. Gessner characterized the work -5 pages of Hanno's text and 12 pages of his notes-- as the "labor of a short day." ${ }^{89}$ Similarly requests from Jakob Gessner prompted the bilingual edition of Cassius's Naturales et medicinales quaestiones (1562) and a 230-page De anima which Gessner added to his edition of Johannes Lodovicus Vives's work on the topic..$^{00}$ In 1563 Gessner took the initiative in proposing to Jakob a text by the deceased Jodocus Willich; a relative of Willich's had sent the manuscript (along with a dedication he had written) to Oporinus of Basel, but Oporinus had neglected to print it and was happy for Jakob Gessner to do so. Gessner wrote a new dedication (to Iohannes Pontisella, rector of the Latin school of Chur in the Graubünden) in which he reflected on the proceess: "I would rather have abstained from this not very glorious work, but I am in the habit of being all too ready to gratify the printer and promote the works of the deceased." ${ }^{91}$ Gessner's depiction of himself as easily swayed by the requests of printers seems worth taking seriously, even though it also served as a modesty trope by emphasizing that Gessner published these works in haste and at the behest of others.

Gessner cultivated close relations with multiple printers. He worked most often with Christopher Froschauer who published twenty-four of Gessner's books from his earliest years (Compendium ... de urinarum differentiis, 1541; Catalogus plantarum 1542) down to his latest ones (De libris a se editis, 1562; Viaticum novum, 1565). Froschauer also printed all of his largest and most expensive books, in the Bibliotheca and Historia animalium series. Gessner reserved pride of place in the Pandectae to Froschauer, addressing the first of the dedications to him, though he denied that this was a mark of higher esteem: "I have assigned first place to you Froschauer, not deliberately or from a special plan but by chance, as I shall shortly say," but because Froschauer had 
published so many works relevant to grammar and philology, the themes of the first book of the Pandectae. In protesting that he did not, Gessner suggests that he did in fact have in mind the extra honor of giving Froschauer the first and most visible dedication of the volume. ${ }^{22}$ Gessner complained about Froschauer in print occasionally, observing in the Bibliotheca universalis that in the publication of Stobaeus "not a few [sententiae] were left out that should have been added to the heel of the volume while I was absent in Italy but were omitted by the inattention of the printer." ${ }^{{ }_{93}}$ Gessner also disagreed sometimes with Froschauer's commercial decisions. He explained of the Greek and Latin Sententiae of Antonius and Maximus printed in 1546 that he "wanted to publish [together] Latin and Greek versions of these loci but the printer Froschauer thought it was better to sell them separately," so they appeared in two separate volumes. ${ }^{94}$ Similarly Gessner complained in a letter about Froschauer's decision to have copies of the illustrated volumes colored as rapidly and cheaply as possible. ${ }^{95}$ But Gessner also appreciated Froschauer's need to make ends meet in a difficult business and maintained a strong working relationship with him.

The printers that Gessner mentioned most frequently in his dedications were his relatives Andreas and Jakob Gessner with one or both of whom Gessner published fourteen works starting in 1552, when Gessner rushed his Thesaurus Evonymi into print under a pseudonym, down to the fat octavo of De omni rerum fossilium genere (1565)..$^{96}$ In 1548 Gessner had dedicated his edition of Ermolao Barbaro's compendium of natural philosophy to young Jakob Gessner when he was still a student, but since he was not yet a printer he did not receive a dedication in the Pandectae. Another printer was the object of two dedications from Gessner: Thomas Iunta of Venice, to whom Gessner dedicated both the last book of his Pandectae in 1548 and his twenty-folio-page discussion of Swiss and German thermal baths within a longer book on spas published by Iunta. This dedication, in which Gessner encouraged Iunta to come visit spas in his area, constitutes an unusual case of an author dedicating a piece of writing to the printer responsible for printing it. Gessner also cultivated relations with a number of other printers with whom he published more than one work: in Basel, Winter in the early years (3 works), then Curio (2), Oporin (4), and Froben (2); in Strasbourg, Rihel (4) and in Geneva, Henri Estienne (2). In addition Gessner published single works with a further seven printers in Lyon, Basel, and Venice. ${ }^{97}$ Reflecting in 1562 on the sequels to his Bibliotheca which omitted things without his consent, Gessner noted that "printers look to profit rather than to the desires of the authors or the utility of the readers." ${ }_{98}$ Gessner's clear-headed understanding of the tensions inherent in the relations between learned authors and printers was no doubt helpful in his ability to work effectively with printers to produce supplemental income for himself and for them through a steady stream of learned publications which also benefitted the common good of the Republic of Letters.

\section{Conclusion}

Gessner's strategy of publishing many different kinds of works, in multiple fields of learning and varying sizes (from 16mo to folio), dedicated to a wide range of people and in close collaboration with the interests of printers, can be contrasted with the strategy of another naturalist of the same generation as Gessner but longer-lived. The dedication strategy of Ulisse Aldrovandi (1522-1605), studied by Laurent Pinon, was quite different from Gessner's.9 With the explicit aim of outdoing Gessner, Aldrovandi sought to publish large multi-volume works of illustrated natural history and sought funding for the expenses of gathering specimens and making images from life especially 
from the wealthy cardinals of his day. Cardinal Montalto, to whom Aldrovandi dedicated three books of his Ornithology $(1599,1600,1603)$ funded the second of these volumes but did not become the reliable patron that Aldrovandi sought, despite Aldrovandi's lavish engraved title page and a fulsome dedication. The dedication of Aldrovandi's book on insects (1602) to Francesco Maria Duke of Urbino also failed to yield a major patron. In his search for a patron Aldrovandi gifted 82 copies of his Ornithology (worth an impressive sum), including 17 copies he gave to various cardinals, seeking funds from which to publish the many other works of natural history he had prepared. The lack of response to his campaign doomed the bulk of Aldrovandi's vast works to remain unpublished at his death. Only the proceeds of the sales of Aldrovandi's valuable collection of naturalia which he had bequeathed to the City of Bologna made possible the posthumous publication of a further thirteen volumes of his natural histories down to 1648. Hundreds of volumes of manuscripts remained unpublished in the University Library of Bologna. Gessner too died leaving manuscripts behind, including a Historia plantarum, the publication of which was spectacularly delayed until 1753 and $1771 .^{100}$ Nonetheless Gessner's method of accumulating support for many quarters seems to have been remarkably effective by contrast with Aldrovandi's single-minded pursuit of a major donor.

Gessner's case highlights the complex roles of dedications in the Renaissance which were not always limited to bids for patronage. Gessner used his dedications as opportunities to bring to public attention his achievements and aspirations and to navigate both local hierarchies and international networks seeking access to books, images, information and support across confessional difference and geographic distance. Even when we lack full details about their actual impact, early modern dedications like Gessner's reward careful study with the insight they offer into an author's relationships with printers, peers, and patrons which shaped both the process and the results of research and writing.

' I am indebted to generous colleagues for their comments and corrections: Anja Goeing, Anthony Grafton, Urs Leu, Paola Molino, Mikhail Sergeev and the editors of this volume. I am grateful to those who organized and attended my talk at CalTech, especially Mordechai Feingold and David Hall. Warm thanks to Samantha Wesner for help with research and formatting, and to Tom Keeline for his expert reading of the Greek dedications.

On the conception of E-rara in 2008 see Leu 2014, 53.

Scanning also introduces distortions of its own, including traces of hands, blurred scans, and duplicate pages. The multiple digital copies of Mithridates (1555) also omit, without indicating that they do, the foldout table appended to the work, present in the volume itself. See for example the copy with call number Regensburg 999/Ling1a and its digitization at the Bayerische Staatsbibliothek (hereafter BSB). The table may have escaped the notice of the scanner and certainly did not fit the format of the rest of the octavo book.

- For example one of the copies of Gessner's 1565 De omni rerum fossilium genere on E-rara contains only the first of the ten texts in that collection (see the digitization of call number NG 1910 from the Zentralbibliothek Zurich, hereafter ZB). Or the copy digitized by the BSB of David Kyber. Lexicon rei herbariae (1553) contains a thoroughly blacked out sentence fragment on p. 7 concerning the afterlife: "Quanquam enim credendum est, sanctos qui in vera per unicum Christum fiducia obdormiunt, pari inter se omnes amore feruoreque in vita coelesti coniunctos iri." I cite Gessner's works by title alone; further bibliographical details are provided in the appendix.

s Compare the E-rara pdf of Gessner's Bibliotheca universalis, f. 454v-455r with the edition of 1966.

- See Wellisch 1984, section A, 31-100. 
The later editions I have included are the fourth edition of the Dictionarium graecolatinum (1545) and the second edition of the Onomaticon (1549), which were the earliest editions of these works to contain a dedication by Gessner; and the second editions of the Icones avium (1560) and Icones animalium (1560) which each included a new dedication in addition to reprinting the dedication present in the first editions of these works.

- Gessner chose as dedicatee a mutual friend, Christophorus Piperinus, minister in Sigriswil, Bern. See Stockhornii et Nessii in Bernatium Helvetiorum ditione montium ... brevis descriptio in Valerii Cordi Annotationes in ... Dioscorides libros V (1561), E-rara pdf 486ff. I refer to image numbers in the pdf listed in the appendix when the printed pagination is difficult to follow, e.g. because of multiple pagination sequences. I am grateful to Urs Leu for bringing to my attention another such example, in which Gessner dedicated to Abel Werdmüller a work by Abel's recently deceased father Otho that Gessner published as part of Johannes Fabricius Montanus 1555.

- Aretius was a friend, correspondent and professor of classical languages and theology in Bern; see Gessner 1577, ff. 115v-122v; and Wellisch, 90. On classicizing names, see Bodenmann 2009; and Taylor and Mosher 1951, ch. 2.

${ }^{10}$ For examples of "praefatio" see Valerii Cordi Annotationes (1561), Galeni Opera (1562). "Epistola dedicatoria" occurs in Apparatus (1542), Sententiae Antonii et Maximi (1546, Greek volume), De rerum fossilium figuris (1565).

"Works with a "Gessner to the reader" only: Actuarius. De medicamentorum compositione (1540); Enumeratio medicamentorum (1543); Galeni opera (1549); Epitome (1555); Viaticum novum (1565).

12 "Icones quidem propter temporis angustiam aliasque occupationes descriptionibus non licuit." Valerii Cordi Stiripium descriptionis liber V (1563), sig. aijr. For a broader discussion of his paratexts see my "Conrad Gessner's Paratexts," Gesnerus 73/1 (2016), 73-123; on Gessner's habits of thanking and citing, see my forthcoming article, "Conrad Gessner."

${ }^{13}$ The 500" anniversary of Gessner's birth has prompted renewed attention to Gessner, including: Urs Leu, Conrad Gessner (1516-1565), Universalgelehrter und Naturforscher der Renaissance. Zurich: Verlag Neue Zürcher Zeitung, 2016; Facetten eines Universums. Conrad Gessner 1516-2016. Ed. Urs B. Leu and Mylène Ruoss. Zurich: Verlag Neue Zürcher Zeitung, 2016; a special issue of Gesnerus; and my "Printing and Humanism in the Work of Conrad Gessner," Renaissance Quarterly, forthcoming 2017. Earlier accounts of Gessner's life include Braun 1990; Wellisch, 1-25; Ley 1929; Hanhart 1824; and Simmler 1566. See also Serrai 1990; Leu 1990; and Leu, Keller, and Weidmann 2008.

${ }_{14}$ "Accipe igitur, quicquid hoc et quantulumcumque est libelli, meae erga te observantiae pignus perpetuae, et amoris monumentum summi." Hanno Carthaginensium ducis navigatio in Ioannis Leonis Africani de totius Africae descriptionis libri IX (1559), E-rara pdf 566ff.

${ }^{15} O E D$ records first uses in French in 1526, in English in 1542 in a translation of Erasmus's Apopthegms; "maecenas" does not appear in the Thesaurus Linguae Latinae.

10 On the distinction between patron and Maecenas, see Viala 1985. On dedications, see Genette 1997, ch.6; Schottenloher 1953; Moennighoff 2008; Jancke 2002, 141-52; Offrir un livre, 2003; and Rice 1971.

"See the case of Jean Bodin in Blair 2013, 138-39.

« "Ea quidem lege, ut a fronte libelli significarem Lectori, nec suo [Gessner's], nec Guilandini iussu aut voluntate evulgata haec esse, sed meo unius arbitrio." Nicolaus Philesius, "Ad lectorem," in De stirpium aliquot epistolae (1557), sig. A2r.

"2 ZurKinden/Zerchinta also appears as a correspondent in Gessner's Epistolarum medicinalium libri III (1577), ff. 130v-131r. In his dedication of Historia animalium II (1554) to Johannes Steiger, also a city councilor in Bern, Gessner requested that Steiger send Gessner's greetings to ZurKinden.

${ }^{20}$ See Terrall 2002.

21 "Et patrono suo colendissimo. Con. Gessnerus d.d." Evonymi thesaurus (1552), ZB call number Md E 377, digitized on E-rara.

"De libris a se editis (1562), sections 37 ("Hunc librum cum in gratiam Andreae Gesneri patruelis mei, novi tum typographi, immaturum ederem, nomen meum adderem nolui") and 60 ("meum [nomen] enim non ponere placebat, ne quis sutorem ultra crepidam mihi obijceret."). Also Wellisch, 91.

${ }^{23}$ Holzknecht 1966; and, on methods of inscribing authorship into the preliminaries, Brown 1995.

${ }^{24}$ Niccolò Perotti to Francisco Guarneri, as edited and discussed in Monfasani 1988, 26, sentences 20-21. I am grateful to Anthony Grafton for this reference. 
${ }^{2}$ On Erasmus's remarkable publishing savvy, see Jardine 1993, and Vanautgaerden, 2012. Vanautgaerden enumerates the 221 works in his appendix.

${ }^{26}$ See Hoyoux 1944, 43-49.

${ }^{27}$ See Hoyoux, 41 and 34-41 for the list. Vanautgaerden notes that dedications were important especially before 1516 when Erasmus became counselor to prince Charles; most notably his edition of Lucian was divided into 7 parts, each with a different dedicatee. Vanautgaerden, 82.

${ }^{28}$ I count seventeen works containing more than one dedication and eight cases of dedications addressed to more than one individual.

${ }_{29}$ The record for most dedications in one publication that I have come across is 23 dedications in Paolo Zacchia, Quaestiones medico-legales (1620), as discussed in Pinon 2009, 63, n. 14.

${ }^{30}$ Dedications by others (not Gessner) in this corpus include: Ephesii Scholia, 1541 (Magus Leonicus, pdf 109); Porphyrii institutiones, 1542 (Joachim Perionius, pdf 6); Antonij Thylesii opuscula aliquot 1545

(Joannes Ludovicus Brassicanus, pdf 122); Sententiae Antonii et Maximi 1546 (Vincentius Obsopaeus, pdf 278; Conrad Clauser, pdf 317); Ermolao Barbaro. Compendium 1548 (Hieronymus Wildenbergius, pdf 128); Chirurgia 1555 (too many to list!); Valentini de anima 1563 (Vitus Amerbacius, pdf 469; Philip Melanchthon, pdf 711); De omni rerum fossilium genere 1565 (Kentmann, pdf 10 and 240; Georg Fabricius, pdf 288; Severinus Goebelius, pdf 358).

${ }^{3}$ This text is available in Weber 2003, 16-21, translated from the French version in Coolidge 1904, iii-xvii. Also mentioned in Schottenloher, 45.

${ }^{32}$ The appendix lists the lengths of dedications. For other long dedications see: Apparatus et delectus (1542), Stobaeus (1543), Martial (1544), Antonij Thylesii opuscula aliquot (1545), Bibliotheca universalis

(1545), Historia animalium I (1551), Historia animalium IV (1558), Marcus Aurelius (1559), Ars magirica (1563), Dioscorides. De curationibus (1565), De omni rerum fossilium genere (1565). The shortest are to Gregorius Laetus in Sententiae Antonii et Maximi (1546), Beck von Beckenstein in Mithridates (1555), and Lemnius in Nomenclator piscium (1560).

${ }^{33}$ One of these was reprinted in the nineteenth century in Botfield 1861, 518-22 (Gessner's Greek dedication to Anton Werther von Beichlingen in his edition of Marcus Aurelius, 1559). Botfield also reproduces

Gessner's Latin dedication to Johann Jakob Fugger in his edition of Aelianus (1556), 482-85.

${ }^{34}$ "Est enim vere philosophia divinum bonum. ... [N]on iniucundam eius in nomina vestra inscriptionem vobis futuram existimavi." Onomasticon (1549), sig. ++3r-v.

${ }_{3 s}$ "Quod si authoritate tua effeceris, ut viri aliqui docti apud vos, illarum avium quae in Anglia reperiuntur ultra eas quas hic exhibui, effigies mihi communicent, librum hunc alias ijs ipsis iconibus, et alijs forte (si quas aliunde interim nanciscar) Domino Opt. Max. vitam largiente, augendum curabo." Icones avium (1560), 128. "Thomas Erastus Helvetius, civis meus ... icones aliquot animantium raras, Balthici praesertim maris aquatilium, te possidere adiecit, quas mihi communicaturum te sis pollicitus, si qua commoditas tanto locorum intervallo mittendi daretur." De piscibus (1556), 94.

${ }^{36}$ Hoyoux notes (41) that Erasmus was exceptional in not following this pattern.

${ }^{37}$ See Wellisch, 40-43. Gessner calls his edition of Martial in 1544 "the most useful of everything I have published after the translation of Stobaeus." "Hunc certe laborem post translationem Stobaei utilissimum omnium quae publicavi obijsse mihi videor." Bibliotheca universalis (1545), f. 182v.

${ }^{38}$ Not much is known about Beck von Beckenstein (whose name Gessner spelled in a variety of ways); on his ownership of Greek manuscripts, see Serrai, 90.

3s "Haec ex inscriptione mea tibi habeas, clarissime Leonharte, veluti vinculum inseparabile nomini tuo ad posteros propagando futurum: partim quoniam libelli per se sunt eximij, nec indigni amplitudine tua: partim quod virtutis tuae splendore, etiam ipsi proculdubio fient illustriores." Antonij Thylesii opuscula aliquot (1545), sig. a4v.

to "Quod si Mecoenas etiam aliquis benignus contingat, cuius auspicijs res peragatur, perfectior tota historia efficietur: sin minus (ut nunc sunt divites plaerique avari ac sibi tantum, non bonis studijs vivunt) non desinam tamen pro virili mea tam plausibile argumentum excolere." Bibliotheca Universalis (1545), f. $182 \mathrm{v}$.

" "O ego si forem dives, quam recte pecunijs uti, quam beneficus alijs esse vellem? difficillimum tamen est factu, et a paucissimis praestatur, ideoque laudandum constantius, quanto contingit rarius. ... Accedit gloriae tuae non exigua pars, quod luxu et ocio in tanta occasione post habitis, vitam frugalem degas, et 
bonas amplectare literas, et literatis summopere faveas, denique pro virili tua disciplinas et sapientiae studia promoveas." Antonij Thylesii opuscula aliquot (1545), sig. a3v-4r.

${ }_{42}$ "Te vero unum ut virtutis et nobilitas excellentia florere, sic etiam doctrina et animi promptitudine ad Bibliothecam instruendam plaerosque omnes tui ordinis homines a tergo relinquere animadverti."

Bibliotheca universalis (1545), sig. *5v.

${ }_{43}$ "His ego rationibus defendi poteram, et illustri viro Caesareae maiestatis a consilijs D. Leonardo Beckh a Beckhenstain, Mecoenati meo et patrono optime merito, ... ita hunc etiam iure consecrare." Pandectae (1548), sig. *2r. "Hanc autem qualemcumque tabulam, nobilissime et sapientissime Leonarde, tuo potissimum nomini nuncupare volui, ut et quanti perpetuo te facerem merito tuo inde conijceres: et si quid ad augendum emendandumve Mithridatem nostrum, cum alibi tum circa Germanicae linguae antiquitatem et vetustissima carmina afferre posses, (potes autem pro doctrina et diligentia tua his in rebus plus quam alius quisquam) id promptius citiusque ut faceres, et me tui studiossimum amare pergeres." Mithridates (1555), foldout table. ${ }^{4}$ Leu 2016, 167-174; Braun, 89-90.

«s "[Q]uale profecto hactenus, in Germania quidem, nullum videre mihi contigit. Quamvis enim copiosas librorum moles inspexerim alibi, magna tamen illorum pars, aut inutilibus omnino, aut plane vulgaribus libris constabat. Vestra [bibliotheca] vero, ut non adeo multos, sic certe praestantissimos, rarissimos, plaerosque nondum evulgatos, et Graecos, id est antiquos, habet codices. ... [C]larissimo nomini vestro dedicare volui: ut commode petendi aliquos ex Bibliotheca vestra codices, occasione ista fruerer." Sententiae Antonii et Maximi (1546), Greek volume, sig. +2r-v.

${ }^{46}$ "Quod si hunc laborem tibi non ingratum fuisse declaraveris, animum mihi addideris ut in animalium historia cum picturis singulorum, exquisito et magno opere, alacrius subinde pergam." Sententiae Antonii et Maximi (1546), Latin volume, sig. *2r.

"7 "Te certe unum omnium hoc munere dignissimum iudicavi: et multis hactenus annis, quibus in eo perficiendo elaboravi, animo meo id tibi nec temere nec immerito destinavi. ... Testatur amplissima illa quam paras omne genus librorum BIBLIOTHECA, tanto quidem studio, ut plerosque etiam reges in eo iam aut aeques aut superes." Historiae animalium liber III (1555), sig. a4r-v.

«s "D. Ioanni Iacobo Fuggero... Domino et Mecoenati suo... [Q]uoniam tu Graecum codicem manuscriptum vetustissimum ex publica amplissimae civitatis vestrae Bibliotheca mihi impetrasti, et alterum ex proprio librorum tuorum thesauro addidisti." Aeliani opera quae extant (1556), sig. alpha 2r.

4s "Redeunti igitur ad te Aeliano tuo, iam integro, emendato, bilingui, publico, facilem ac benignum te praebe, et in bibliothecam tuam veluti hospitij iure admitte." Aeliani opera quae extant (1556), sig. alpha $2 r$.

so "Huius de animalibus libros a Petro Gillio Latinitate donatos, nostra memoria potentissimum Gallorum regem Franciscum grato et liberali animo accepisse constat." Aeliani opera quae extant (1556), sig. alpha $2 \mathrm{r}$.

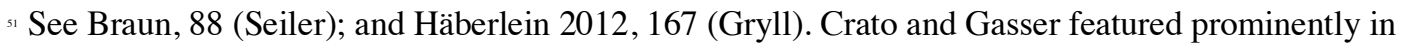
Gessner's Epistolarum medicinalium libri III, ff. 1-22v and 22v-44r respectively. On Crato see Louthan 1994. "Peto praeterea ut per occasionem in Photij patriarchae Catalogo authorum quos legit (quem Augustae apud vos in generosi viri D. Io. Iacobi Fuggeri Mecoenatis mei benemeriti nobilissima Bibliotheca Graece manuscriptum vidi) locum, si modo est aliquis, de Epiphanio eiusque scriptis inquiras..." Sancti Patris Epiphanii de XII gemmis (1565, in De omni rerum fossilium genere), sig. (a)3r. Discussed in Schottenloher, 97, 203. On Gessner's exchanges with Occo, see Delisle 2006, 36-39.

s2 "Salutant te cum alij apud nos eruditi viri, tum praecipue Heinrychus Bullingerus, Rodolphus Gualtherus, ecclesiarum apud nos antistites, et Ioan. Frisius noster. Tu ex me Wolfgango Musculo, Michaeli Cellario, Bernardino Ochino Senensi, Ioanni Heinrycho Helt, et Xysto Betuleio, viris mihi maxime colendis salutem dicito." Sententiae Antonii et Maximi (1546), Latin volume, 346.

ssee Kusukawa 2012, 59.

${ }^{54}$ None of these presentation copies has been identified yet.

ss See Nutton 1985, 96. See the entry of March 7, 1561 in the 1561-62 Calendar of State Papers http://www.british-history.ac.uk/cal-state-papers/foreign/vol4/pp1-16\#fnn1 The Cecil papers record a "short table of divers sums disbursed between 26 May and 4 Aug. 1561, by Sir Wm. Cecil, at the Queen's command. ... 6l. to Conrad Gesner, 'in reward for his book De Animalibus.'" Available online at 
http://www.british-history.ac.uk/cal-cecil-papers/vol1/pp257-263. I am grateful to Samantha Wesner for this find.

ss "Labores sane mei (ut nihil de sumptibus pro ea tenuitate dicam) immensi fuerunt." "Alij etiam qui nuper de aquatilibus scripserunt in Gallia Italiaque, Pontifices aut Cardinales locupletes habuerunt Mecoenates. [E]go unus cum patronum et Mecoenatem hac in re hactenus desyderem, eo venia sum dignior, sicubi expectationi non satisfecero. [S] umptibus enim alicubi opus erat, non paulo quam meae facultates sint maioribus." Historiae animalium liber IV (1558), sigs. a6r and a5v.

${ }^{5}$ See Braun, 71, 136, 143-44.

${ }^{s 8}$ Historiae animalium liber IV (1558), sig. [a5]v.

ss "[Q]uarum utriusque [incomparabilis virtus tua et doctrina illustris] cum ante paucos annos Augustam Vindelicorum, (ubi tum cum Caesare eras,) venissem, gustum ac fructum non mediocrem cepi." De anima liber in Valentini de anima et vita libri tres (1563), 720 (pdf 1019). "Primum ut amicitiam mutuam foeliciter superioribus annis Augustae Vindelicorum, cum ad mensam illustris viri Ioan. Iacobi Fuggeri convenissemus, incoeptam, hoc ceu vinculo inter nos obstringerem." Valerii Cordi annotationes (1561), 236 (pdf 494).

so "Mihi quidem frequentem, et pleno omnium ore de virtutibus tuis doctrinaque celebrem famam, Paulus Scalichius Comes Hunnorum, (antiquissima generis nobilitate illustris, et eruditione multijuga...) verissimam esse iampridem asseruit: et eandem nuper cum alij quidam non vulgares et fide digni viri, tum praecipue Ioannes Sambucus ... plane confirmarunt." Nomenclator aquatilium animantium (1560), sig. aa2r. Paul Scalich made an entry in Gessner's liber amicorum; see Durling, 1965, 145 and 156. On Sambucus whose dedication practices offer a rich case for comparison with Gessner's, see Visser 2005, especially ch. 4.

"On Erasmus's reliance on these brokers, see Hoyoux, 52. Also Kusukawa, 84, notes the importance of intercessors especially for the Emperor. Schottenloher, 197-208, gives examples of works dedicated to those who helped secure privileges too.

62 "Accepi tandem piscium Oceani Germanici quas ad me dedisti Eicones tam diu desideratas ornatissime Echti." Xenocratis de alimento ex aquatilibus, in Iani Dubravii de piscinis (1559), sig. A2r. I have found nothing about Echt beyond the identification in Serrai, 328.

${ }_{63}$ "Quamobrem et propter tot tantaque divina in te beneficia ex animo tibi gratulor, et inter clientes tuos adnumerari vehementer cupio." Appendix (1555), sig. *3r. In 1565 Gessner mentioned that von Niedbruck had sent him a manuscript some years earlier and bemoaned his premature death; Sancti Patris Epiphanii de XII gemmis (1565, in De omni rerum fossilium genere), sig. (a)3r.

${ }^{6}$ See Bibliotheca universalis (1545), f. 180r-v. And: "Sed typographus me inscio et praeter omnem expectationem meam, exiguam duntaxat accessionis meae partem adiecit, reservans sibi forte auctarium ad sequentes etiam editiones." De libris a se editis (1562), section 1, sig. A2r.

"s "Ostendit nobis aliquando doctissimus vir Arnoldus Arlenius Peraxylus Graecae supellectilis tuae catalogum, et prolixas excellentiae tuae in utraque lingua per omnes philosophiae gradus laudes narravit. ... Etenim brevi magna doctorum pars cognoscet quinam egregij libri superstites apud te lateant, cum eorum mentionem in bibliotheca nostra, sive scriptorum omnium Catalogo iam primum a nobis absoluto legerint, expresso toties fere nomine tuo, quot libros Graecos rariores te possidere cognovi." Lexicon Graecolatinum (1545), sig. +2r-v.

${ }^{6}$ Mendoza's library catalog is one of five catalogs that Gessner named, alongside the Vatican and Medici library catalogs. Bibliotheca universalis, sig. [*6]v.

${ }^{6}$ See Braun, 40-41.

${ }^{6}$ Froschauer used the same woodcut of Gessner in Icones avium (1555) at the end of the index and in Historia animalium (1555) on the verso of the title page. I have also found it present in one copy of the Icones animalium of 1553, placed under the dedication, though the woodcut is not present in the digitized copy from E-rara; see Stanford Library copy KB1553.G4.f.

${ }^{\circ}$ For a few specifics about these payments see below note 85 .

${ }^{70}$ See Wellisch, 17. For Gessner's complaints about his early employment, see Bibliotheca universalis, $\mathrm{f}$. 180r.

" "Ne vero sine patrono in manus hominum ... liber hic imperfectus perveniret, unius defuncti loco plures excellentissimosque patronos [the University of Wittenberg] delegi." Gessner, Valerii Cordi annotationes (1561), sig. a iiiv (pdf 11). Gessner also applied these terms to Steiger ("patronum et spectatorem 
praecipuum" Historiae animalium liber II, pdf 126), Gryll ("iudicem simul ac patronum" De raris herbis, sig. A2r), Bullinger (twice, see below), Lauraeus ("patronum ... qui his de rebus et recte iudicare posset," Valerii Cordi annotationes, 236, pdf 494), and Alexandrinus ("censorem simul graviorem et patronum meliorem," Valentini de anima, 720).

"Quoted in footnote 21.

${ }_{73}$ "Et aequissimum est profecto huiusmodi opus, quod gymnasio vestro (cui studiorum meorum incunabula simul ac progressus debeo) aliquando usui futurum sperarem, non alijs offerri quam vobis, quorum beneficio atque liberalitate ferme a puero in hunc usque diem bonis literis vaco." Martialis epigrammata (1544), sig. *4v. On this expurgated edition, see Leu 2014, 197-208.

${ }_{74}$ "Non solum enim patronum te et vindicem cum Athenagorae, tum Gesneri interpretis, sed arbitrum atque iudicem esse cupio." Athenagoras (1557), 80.

${ }_{7 s}$ "Debueram enim iamdudum aetatem, propter perpetuam in me benevolentiam tuam, propter multa et magna beneficia, aliquod animi grati et memoris argumentum tibi deferre: quamvis liberalitas tua id non requirat." Athenagoras (1557), 79.

${ }^{76}$ On dedications to cities, see Schottenloher, $188 \mathrm{ff}$.

$"$ "In den züricher Akten steht als die erste eine Widmung Konrad Gessners verzeichnet, welcher dem Rate ('Meinen Gnädigen Herren') im September 1551 sein Buch von den vierfüßigen Tieren 'verehrt' hatte. Er erhielt dafür als Gegengabe 10 Malter Kernen (Roggen oder Weizen) und 10 Eimer Wein jährlich." Kapp 1886-1923, Band 1, ch. 5, 319 (available from de.wikisource.org) I am grateful to Kusukawa, 56, for this reference.

${ }^{78}$ As quoted in note 71.

79 "Mox autem ipsum argumentum suggerebat, honestissimum Ordinem vestrum, hoc qualicunque dono dignissimum, simul etiam patronum mihi meoque huic operi futurum, imprimis mihi deligendum, quoniam inclyta urbs vestra ad maximum nobilissimumque nostrarum regionum et ferme totius Europae flumen Rhenum condita, summum Helvetiae nostra decus et ornamentum existit." Nomenclator aquatilium amantium. Icones... (1560), 279.

${ }^{80}$ Letter of Simon Sulzer in Basel to Gessner, Staatsarchiv Graubünden in Chur, shelf mark: D V/37 C 36.06.26. Many thanks to Urs Leu for this information and reference.

${ }_{81}$ "Atqui beneficentia vestra multo magis nunc indigent pupilli, quos iam iam moriturus parens fidei vestrae commisit." Dioscorides. De curationibus (1565), sig. [a6]r.

\&2 "Quanquam nemo ira iudicare debet, ac si librorum ordo, quos alijs prius, alijs posterius dedicavi, discrimen aliquod inter typographos constituat. Non enim ordinem, sed argumentum ut plurimum respexi, in quo quis vel numero vel dignitate excusorum a se librorum excelleret: et alicubi forte ut primum quis in mentem venit, ita liber aliquis ei dicatus est." Pandectae (1548), sig. [6]r. See Leu 2014, esp. 59-67.

\& "Etenim in studiosorum gratiam ut Opus hoc universum composui, ita singulorum eius librorum inscriptiones feci in typographorum illorum nomina, qui hoc tempore maxime florerent, ac optime de bonis studijs meriti essent, ut simul hac occasione quinam ex officinis eorum libri prodivissent, quotquot meminisse poteram, commemorarem: simul ut gnaviter pergerent pro virili mea illos animarem. Excitatur enim fere ad maiora, qui anteactos labores suos quamplurimis et utiles et gratos fuisse, seque publicis illorum gratia laudibus, tanquam suae praemio virtutis, affici celebrarique animadverterit." Pandectae (1548), sig. [6]r.

${ }^{84}$ See Wellisch, 14; see the German translation in Ley, 21-22.

"See Wackernagel 1881, 20 re Elias Philippinus (paid $15 l 2$ s 2d "pro Galeni recognitione"); 39 ("Gessnero pro praefatione," $15 l$ from Froben) and 41 ("Gessnero d.d." $15 l$ from Episcopius). I am most grateful to Urs Leu for the information concerning Bullinger and the reference to his "Haushaltungsbuch oder

Rechnungsbuch," Zentralbibliothek Zürich, Ms K 40. For more discussion of Gessner's finances see Blair $2017 \mathrm{~b}$ and Leu 2016a, 348.

${ }^{86}$ See Wellisch, 13. On the relations between these different units of currency see Guthrie 2003, 34.

${ }^{8}$ See Wellisch, 91-92. I did not find this edition of Galen digitized and relied on Wellisch's collection of microfilms and a physical copy at the Huntington Library.

${ }_{s 8}$ "[Q]uoniam typographis placuit me in eos praefari, quibus ego propter multa praeclara eorum in me beneficia, quamvis probe tenuitatis meae conscius, meam operam negare non sum ausus." Galeni omnia quae extant (1562), sig. a+3v. 
s "Cum his diebus patruelis meus Andreas Gessnerus, Ioannis Leonis Africam suis typis cuderet: eique auctarium aliquod novum a me addi contenderet, nec ocium ad maiora mihi suppeteret, subito Hannonis Navigationem, qua is maximam Libycae orae partem lustravit, dieculae fere opera, Latinam feci et simul Scholia quaedam, nimis quidem festinanter conscripta, adieci." Hanno Carthaginensium ducis navigatio (1559), sig. alpha $2 \mathrm{r}$ (pdf 568).

so "Patruelis meus typographus hoc ipso tempore sub praelo haberet ... meque rogaret ut novi aliquid adderem de meo..." Valentini de anima (1563), 721 (pdf 1020). "Nunc tandem, postulante typographo patrueli meo, ut praelo ocioso aliquid suppeditarem, ex schedarum mearum acervo hunc libellum deprompsi." Cassii Naturales et medicales quaestiones (1562), sig. A2v.

" Maluissem equidem, praesertim in proprijs lucubrationibus, si quisquam alius, occupatissimus, abstinere hoc labore minime glorioso: sed nimium fere ad gratificandum typographis facilis esse soleo, et ad promovendas defunctorum lucubrationes." Willich, Ars magirica (1563), sig. *3r-v.

"2 "Principem vero tibi locum Froschovere inter claros aetatis huius typographos assignavi, non de industria quidem, neque primario instituto, sed casu, ut modo dicam." Pandectae (1548), sig. [6]r.

"s "Supersunt tamen adhuc non pauca, quae calci voluminis adijcienda me absente in Italia typographorum incuria omisit: sed cum illa, tum veterum exemplarium collationes brevi fortassis aedentur separatim." Bibliotheca universalis (1545), f. 182r. This passage was marked for deletion in the ZB copy but is present in the Olms reprint.

94 "Interpretationem hanc Locorum communium a Graecis separari non debere, consilium meum fuerat.... Nunc quoniam aliter visum est Typographo nostro, magis e re sua futurum persuaso, si uterque seorsim vaeneat." Sententiae Antonii et Maximi (1546), Latin volume, sig. *2r.

"See Gessner, Epistolarum medicinalium libri III (1577), 22r (to Crato von Krafftheim, 26 March 1564), complaining that the colors were applied "negligenter" and "defunctorie" because of the printer's avarice; as discussed in Kusukawa, 76.

* This figure includes the reprint of 1557 Athenagoras in 1559 as Theologorum Graecorum libri. Most of these imprints were octavos, with two quartos (De raris et admirandis herbis, 1555, and De piscibus, 1556), one folio (and Theologorum Graecorum libri, 1559), and one 16mo (Hanno Carthaginensis, 1559). Gessner refers to Andreas and Jacob as his "patrueles" which means that they descended from his father's brother, making them cousins or cousins-once-removed. For some details, see Gessner's letter to Crato von Krafftheim of 26 March 1564: "patrui mei nomen est Andreas Gesnerus senior (nam et filium eiusdem nominis habuit) annos nunc octoginta natus, tribunitiae dignitatis, senator, liberorum, nepotum et pronepotum utriusque sexus pater, avus et proavus numero centum et triginta quatuor hoc tempore, quorum maior pars vivit." Epistolarum medicinalium (1577), f. 21v. See Serrai, 50.

"This count omits the Paduan publication of 1557 in which Gessner was not involved (see note 18).

$\because$ "Sed suum plerunque lucrum spectant typographi, potius quam vel authorum voluntatem, vel utilitatem Lectorum solidam. " De libris a se editis (1562), section 25, sig. A6r-v. Gessner also showed his awareness of printers' concerns when he invoked the need to fill the blank pages in a quire, as I discuss in Blair 2017a. "On this aspect of Aldrovandi, see the work of Pinon.

${ }^{100}$ Wellisch, 23-25, provides a brief account. A facsimile of Gessner's manuscripts on plants is available: Conradi Gesneri historia plantarum 1987, 2 vols. 
For DASH table to accompany final submitted version of :

Ann Blair, "The dedication strategies of Conrad Gessner," in Professors, Physicians and Practices in the History of Medicine: Essays in Honor of Nancy Siraisi, ed. Gideon Manning and Cynthia Klestinec (Cham: Springer, 2017), pp. 169-209

Appendix: Gessner's publications and dedications (ordered by date of dedication)

\begin{tabular}{|c|c|c|c|c|c|c|}
\hline $\begin{array}{l}\text { Wellisch } \\
\text { number }\end{array}$ & $\begin{array}{l}\text { Date } \\
\text { of } \\
\text { pub'n }\end{array}$ & $\begin{array}{l}\text { Short Title } \\
\text { format (fol. 4to, 8vo); privilege if mentioned } \\
\text { (imperial, royal [Austria], French, } \\
\text { unspecified); pdf source }\end{array}$ & $\begin{array}{l}\text { Place of pub } \\
\text { Publisher }\end{array}$ & $\begin{array}{l}\text { Dedication } \\
\text { Month } \\
\text { (+ year if diff } \\
\text { from pub yr) }\end{array}$ & Dedicatee(s); length of dedication & $\begin{array}{l}\text { Dedicatee } \\
\text { place/origin }^{1}\end{array}$ \\
\hline \multicolumn{7}{|c|}{ Written in Lausanne } \\
\hline A1 & 1537 & $\begin{array}{l}\text { Lexicon Graecolatinum. fol. 3-year imp priv. } \\
\text { (pdf e-rara) }\end{array}$ & $\begin{array}{l}\text { Basel } \\
\text { J Walder }\end{array}$ & & $\begin{array}{l}\text { none--no mention of Gessner's contribution; see ed of } \\
1545\end{array}$ & \\
\hline A2 & 1540 & $\begin{array}{l}\text { Actuarius. De medicamentorum } \\
\text { compositione. } 8 \text { vo. (pdf Google Books) }\end{array}$ & $\begin{array}{l}\text { Basel } \\
\text { R. Winter }\end{array}$ & & None & \\
\hline A7 & 1542 & $\begin{array}{l}\text { Apparatus et delectus simplicium. 8vo. (pdf } \\
\text { archive.org; some expurgations) }\end{array}$ & $\begin{array}{l}\text { Lyon } \\
\text { J, F Frellon }\end{array}$ & Jan 1541 & $\begin{array}{l}\text { Christophorus Clauserus, archiatros (chief physician of the } \\
\text { city). } 8 \text { p. }\end{array}$ & Zurich \\
\hline \multirow[t]{3}{*}{ A4 } & 1541 & $\begin{array}{l}\text { Actuarius. De differentiis urinarum. 8vo. (pdf } \\
\text { Google Books) }\end{array}$ & $\begin{array}{l}\text { Zurich } \\
\text { Froschauer }\end{array}$ & n.d. & $\begin{array}{l}\text { 1. Petrus Jacobus Et Stephanus, Hispanus Vincentinus } \\
\text { (met in Montpelier). 3p. }\end{array}$ & Spain \\
\hline & & Universalis doctrina Galeni & & June & 2. (pdf p. 96) Albertus Belfort, medicus (met in Lyon). $4 \frac{1}{2} p$ & Graubünden \\
\hline & & Sylva experimentorum Galeni & & Aug & $\begin{array}{l}\text { 3. (pdf p. 341) Claudius Milletus, medicus (met in Lyon). } \\
11 \frac{1}{2} \text { p }\end{array}$ & Lyon \\
\hline A3 & 1541 & Historia plantarum. 8vo. (pdf e-rara) & $\begin{array}{l}\text { Basel } \\
\text { R. Winter }\end{array}$ & Aug & $\begin{array}{l}\text { Heinrich Billing, stepson of bürgermeister Jakob Meyer. } \\
5 p\end{array}$ & Zurich \\
\hline A8 & 1542 & Catalogus plantarum. 4to. (pdf e-rara) & $\begin{array}{l}\text { Zurich } \\
\text { Froschauer }\end{array}$ & n.d. & $\begin{array}{l}\text { Johannes Jacobus Ammianus, bonarum literarum } \\
\text { professor--former teacher and lodger. } 5 \mathrm{p} \text {. }\end{array}$ & Zurich \\
\hline \multicolumn{7}{|c|}{ Written in Zurich } \\
\hline A6 & 1541 & $\begin{array}{l}\text { De Lacte et operibus lactariis. 8vo. (pdf e- } \\
\text { rara) }\end{array}$ & $\begin{array}{l}\text { Zurich } \\
\text { Froschauer }\end{array}$ & June & Jacobus Avienus [Vogel]. 12p. on the Alps. & $\begin{array}{l}\text { Glarus (cf De } \\
\text { libris a se ...) }\end{array}$ \\
\hline \multirow[t]{3}{*}{ A5 } & 1541 & $\begin{array}{l}\text { Michael Ephesius. Scholia in Aristotelis Libros. } \\
\text { 8vo. 7-year priv unspec. (pdf BnF) }\end{array}$ & $\begin{array}{l}\text { Basel: B. } \\
\text { Westhemer }\end{array}$ & Aug & 1. Sebastian Singler [Sinkler], medicus et praeceptor. 31/2p & Basel \\
\hline & & scholia de longitudine et brevitate vitae & & Aug & $\begin{array}{l}\text { 2. (pdf p. 43) Aegidio Scudo [Tschudi], offered hospitality. } \\
2 \frac{1}{2} \mathrm{p}\end{array}$ & Glarus \\
\hline & & scholia de divinatione per somnum & & Aug & 3. (pdf p. 80) Melchior Wirtz, friend since boyhood. 31/2p & Zurich \\
\hline \multirow[t]{2}{*}{ A10 } & 1542 & $\begin{array}{l}\text { Moralis Interpretatio errorum Ulyssis } \\
\text { Homerici. 8vo. (pdf BSB) }\end{array}$ & $\begin{array}{l}\text { Zurich } \\
\text { Froschauer }\end{array}$ & Mar & 1. Pierre Viret, theologus. 2p. & Lausanne \\
\hline & & commentatio de nympharum antro & & Mar & $\begin{array}{l}\text { 2. (pdf p. 35) Beatus Comes [Comte], theologus et } \\
\text { medicus. } 3 p\end{array}$ & Lausanne \\
\hline
\end{tabular}

\footnotetext{
${ }^{1}$ Locations are usually explicit in the dedication; when they were not I have relied on Urs Leu, "Conrad Gessners Netzwerk" In Facetten eines Universums (2016), 66-74.
} 
lucubratio Procli Lycii

2yrii institutiones. 8vo. 7-year priv unspec (pdf BnF) with Compendium de syllogismis authoris incerti

1543 Stobaeus. Sententiae ex Thesaurus

Graecorum. fol. (pdf e-rara)

A15

Enumeratio medicamentorum. in Brasavola Examen omnium catapotiorum sive pilularum

8 vo. imp priv, duration unspec. (pdf BSB)

A12

1544 Heraclides Ponticus. Allegoriae in Homeri

Fabulas. 8vo. (pdf BSB)

A13

1544 Martialis Epigrammata. 8vo. (pdf e-rara Gessner's own copy, with annotations ${ }^{2}$ )

Onomasticon. fol. [used Wellisch mfilm]

Antonii Thylesii. Opuscula aliquot. 8vo. (pdf BSB)

Bibliotheca Universalis. fol. (pdf e-rara, Gessner's own copy with annotations)

A1.4 1545 Lexicon Graecolatinum, 4th ed (first to list Gessner on title page). fol. royal priv unspec. (pdf BSB)

A18.1 1546 Sententiae Antonii et Maximi. (Greek). fol. (pdf e-rara, Gessner's own copy with annotations)

A18.2 1546 Sententiae Antonii et Maximi (Latin). fol. (pdf e-rara)

\begin{tabular}{|l|l|l|}
\hline & (pdf e-rara) \\
\hline A19 & 1548 & $\begin{array}{l}\text { Ermolao Barbaro. Naturalis scientiae totius } \\
\text { compendium. 8vo. (pdf BSB) }\end{array}$ \\
\hline
\end{tabular}

A16.1b 1548 Pandectae. fol. (pdf e-rara) Book II, dialectic

Book III, rhetoric Book I, grammar and philology

\begin{tabular}{|c|c|c|c|}
\hline & Mar & 3. (pdf p. 67) Jean Ribit, prof. of Greek, friend (BU). 31/2p & Lausanne \\
\hline $\begin{array}{l}\text { Basel } \\
{[\text { R Winter }]}\end{array}$ & Aug & (pdf p. 347) Otho Werdmüller, prof of philosophy. $1 \frac{1}{2} p$ & Zurich \\
\hline $\begin{array}{l}\text { Zurich } \\
\text { Froschauer }\end{array}$ & June & $\begin{array}{l}\text { Johannes Jacobus Watenwil [Wattenwyl] and Joannes } \\
\text { Franciscus Negelin [Hans Franz Naegeli], noble city } \\
\text { consuls of Bern. } 8 \frac{1}{2} \mathrm{p}\end{array}$ & Bern \\
\hline $\begin{array}{l}\text { Zurich } \\
\text { Froschauer }\end{array}$ & & None; starts on pdf p 150 with Gessner's "to the reader" & \\
\hline $\begin{array}{l}\text { Basel } \\
\text { Oporinus }\end{array}$ & Jan & $\begin{array}{l}\text { Hieronymus Frikker [Fricker], praefectus of Mendrisio, } \\
\text { Ticino; helped religious refugees from Italy. } 4 p\end{array}$ & Bern, Ticino \\
\hline $\begin{array}{l}\text { Zurich } \\
\text { Froschauer }\end{array}$ & Mar & $\begin{array}{l}\text { Felix Fry [Frey], Heinrich Bullinger, Gaspar Megander, } \\
\text { Erasmus Fabricius [Schmid], and Rolph [Rodolphus] } \\
\text { Gualtherus, ministers, profs of theology, "respected } \\
\text { patrons and preceptors." } 61 / 2 p\end{array}$ & Zurich \\
\hline $\begin{array}{l}\text { Basel } \\
\text { [H. Curio] }\end{array}$ & & None; see 1549 edition & \\
\hline $\begin{array}{l}\text { Basel } \\
\text { Oporinus }\end{array}$ & Feb & $\begin{array}{l}\text { Leonhard Beck von Beckenstein, consiliarius to emperor. } \\
7 p\end{array}$ & Augsburg \\
\hline $\begin{array}{l}\text { Zurich } \\
\text { Froschauer }\end{array}$ & July & Leonhard Beck von Beckenstein. 91/2p & Augsburg \\
\hline $\begin{array}{l}\text { Basel } \\
{[\text { H. Curio] }}\end{array}$ & Aug & $\begin{array}{l}\text { Diego Hurtado a Mendozza, imperial ambassador to } \\
\text { Venice. } 3 p .\end{array}$ & Venice \\
\hline $\begin{array}{l}\text { Zurich } \\
\text { Froschauer }\end{array}$ & Feb & $\begin{array}{l}\text { Johann Welser, Jakob Herbrot, and the Senate of } \\
\text { Augsburg. } 2 p\end{array}$ & Augsburg \\
\hline \multirow[t]{2}{*}{$\begin{array}{l}\text { Zurich } \\
\text { Froschauer }\end{array}$} & Feb & $\begin{array}{l}\text { 1. Johann Jakob Fugger, wealthy merchant. "domino in } \\
\text { Vuyssenhorn and domino suo." } 1 \mathrm{p} .\end{array}$ & Augsburg \\
\hline & & $\begin{array}{l}\text { 2. (pdf p. } 360 \text { ) Gregorius Laetus [Froehlich], } \\
\text { archigrammateus. } 1 / 4 p\end{array}$ & Augsburg \\
\hline $\begin{array}{l}\text { Basel } \\
\text { Oporinus }\end{array}$ & Aug & Jakob Gessner, relative. $2 \frac{1}{2} p$ & Zurich \\
\hline \multirow[t]{3}{*}{$\begin{array}{l}\text { Zurich } \\
\text { Froschauer }\end{array}$} & Sept & $\begin{array}{l}\text { 1. (pdf p. 11) Christophorus Froschauer, Gessner's main } \\
\text { printer to date. } 1 p / 3 p \text { with list of books. }\end{array}$ & Zurich \\
\hline & n.d. & $\begin{array}{l}\text { 2. (pdf p. 98) Joan. Bebelius and Michael Isengrin, } \\
\text { printers. } 1 p\end{array}$ & Venice \\
\hline & Jan & 3. (pdf p. 110) Johannes Oporinus, printer. $1 \frac{1}{2} p$ & Basel \\
\hline
\end{tabular}

\footnotetext{
${ }^{2}$ To identify Gessner's own copies I have relied on Urs Leu, Raffael Keller and Sandra Weidmann, The Private Library of Conrad Gessner (Leiden - Boston: Brill, 2008).
} 


\begin{tabular}{|c|c|c|c|c|c|c|}
\hline & & Book IV, poetics & & n.d. & 4. (pdf p. 130) Nicolaus Brulinger [Brylinger], printer. $1 / 2 p$ & Basel \\
\hline & & Book V, arithmetic & & Feb & 5. (pdf p. 158) Robert Estienne, printer. $1 / 2 p$ & Paris \\
\hline & & Book Vl, geometry & & Feb & 6. (pdf p. 166) Johannes Petreius, printer. 1p. & Nurnberg \\
\hline & & Book VII, music & & Feb & 7. (pdf p. 174) Henricpetri, printer. 1p & Basel \\
\hline & & Book VIII, astronomy & & Feb & 8. (pdf p. 186) Hieronymus Curio, printer. 1p. & Basel \\
\hline & & Book IX, astrology & & Feb & $\begin{array}{l}\text { 9. (pdf p. 202) Joan. Montanus [Berg] and Ulrich Neuber, } \\
\text { printers. 1p }\end{array}$ & Nurnberg \\
\hline & & Book $\mathrm{X}$, divination and magic licit and illicit & & Feb & 10. (pdf p. 210) Wendelin Rihel, printer. 1p & Strasbourg \\
\hline & & Book XI, geography & & Feb & $\begin{array}{l}\text { 11. (pdf p. 226) Paolus Manutius, printer. } 1 p ; 4 \frac{1}{2} p \text { with list } \\
\text { of publications }\end{array}$ & Venice \\
\hline & & Book XII, history & & Mar & $\begin{array}{l}\text { 12. (pdf p. 246) Sebastian Gryphius. } 1 / 2 p ; 6 p \text { with list of } \\
\text { publications }\end{array}$ & Lyon \\
\hline & & Book XIII, mechanical and useful arts & & Apr & 13. (pdf p. 342) Christian Wechel, printer. $1 / 2 p, 4 p$ with list & Paris \\
\hline & & Book XIV, natural philosophy & & May & $\begin{array}{l}\text { 14. (pdf p. 374) Johannes Herwagius, printer. } 1 / 2,1 \frac{1}{2} \text { with } \\
\text { list }\end{array}$ & Basel \\
\hline & & Book XV, metaphysics & & May & $\begin{array}{l}\text { 15. (pdf p. 486) Johannes Gymnicus [Gymnich], printer. } \\
1 / 2 p, 2 \frac{1}{2} p \text { with list }\end{array}$ & Cologne \\
\hline & & Book XVI, moral philosophy & & June & 16. (pdf p. 534) Johannes Frellon, printer. $1 / 2 p, 2 p$ with list & Lyon \\
\hline & & Book XVII, economic philosophy & & July & $\begin{array}{l}\text { 17. (pdf p. 618) Vincentius Valgrisius, printer. } 1 / 2 p, 1 p \text { with } \\
\text { list }\end{array}$ & Venice \\
\hline & & Book XVIII, politics & & July & $\begin{array}{l}\text { 18. (pdf p. 634) Hieronymus Scotus [Girolamo Scoto], } \\
\text { printer. } 1 / 2 p\end{array}$ & Venice \\
\hline & & Book XIX, civil law & & Aug & 19. (pdf p. 670) Thomas Junta, printer. $1 / 2 p$ & Venice \\
\hline A14.3 & 1549 & $\begin{array}{l}\text { Onomasticon (published with Calepino, } \\
\text { Dictionarium). fol. royal priv unspec. (pdf BSB) }\end{array}$ & $\begin{array}{l}\text { Basel } \\
\text { H. Curio }\end{array}$ & Jan & $\begin{array}{l}\text { (pdf p. 1124) Jacobus and Marcus Roestius [Roeist], } \\
\text { Jacobus and Marcus Stapfer, Jacob Habius [Haab], } \\
\text { Georgius Grebel, Georgius Escher, Felix Engelhart, } \\
\text { Heinrich and Georg Rublin [Rubli], Wilhelm and Geroldus } \\
\text { Meier [Meyer von Knonau?], patricians. 5p. }\end{array}$ & Zurich \\
\hline A16.1c & 1549 & Partitiones theologicae. fol. (pdf e-rara) & $\begin{array}{l}\text { Zurich } \\
\text { Froschauer }\end{array}$ & Feb & $\begin{array}{l}\text { Hieronymus Froben and Nicolaus Episcopius, printers. 1p, } \\
21 \frac{1}{2} p \text { with list of books }\end{array}$ & Basel \\
\hline A20 & 1549 & Galenus. Opera. fol. 5-yr imp priv. (pdf BSB) & $\begin{array}{l}\text { Basel } \\
\text { Froben }\end{array}$ & & None; but "Gesnerus medicinae candidatis" & \\
\hline A21 & 1550 & $\begin{array}{l}\text { Aristotelis. Opera omnia. fol. imp priv unspec. } \\
\text { (pdf e-rara) }\end{array}$ & $\begin{array}{l}\text { Basel } \\
\text { Bebel \& } \\
\text { Isingrin }\end{array}$ & & $\begin{array}{l}\text { None; Gessner not mentioned on title page, thanked in } \\
\text { the printer's "to the reader" }\end{array}$ & \\
\hline A22 & 1550 & $\begin{array}{l}\text { Galeni brevis denotatio dogmatum } \\
\text { Hippocratis. in Galeni aliquot opuscula, pp. } \\
\text { 103-6. 8vo. (pdf BnF) }\end{array}$ & $\begin{array}{l}\text { Lyon: G. } \\
\text { Rovillius }\end{array}$ & & None. & \\
\hline A23 & 1551 & Historia animalium I: De quadrupedibus & Zurich & Aug & Consuls and Senators of Zurich. $81 / 2 p$ & Zurich \\
\hline
\end{tabular}


viviparis. fol. (pdf e-rara)

A16.2a

1551 Elenchus (unauthorized publication, as noted in 1551 Historia animalium). (pdf Google Books) 4to.

Hieronymus Tragus. De stirpium ...

facultatibus, tr. Kyber. fol. 7-year imp priv. (pdf e-rara)

Thesaurus Euonymi Philiatri. 8vo. (pdf e-rara)

A34

De Germaniae et Helvetiae Thermis. in De Balneis. fol. priv from pope and senate of Venice (pdf BSB)

Kyber. Lexicon rei herbariae. fol. 7-year imp priv. 8vo. (pdf BSB, some expurgations)

Gessner, Tabulae collectionum in genere

Icones animalium. fol. 8-year imp priv +10 year French priv] (pdf e-rara) [one issue with woodcut at end of dedication at p. 7 of pdf] istoria animalium II: De quadrupedibus oviparis. fol. 8-year imp priv; 10 -year F priv (pdf e-rara)

Appendix Historiae quadrupedum

Enchiridion rei medicae triplicis. 8vo. (pdf BSB)

Heria animalium III: De avium natura. fol. 8-year imp priv +10 -year F priv. (pdf e-rara) [woodcut of Gessner pdf p. 4]

\begin{tabular}{l|l|l} 
A36 & 1555 & Chirurgia. fol. imp priv. (pdf BSB)
\end{tabular}

A16.1

\begin{tabular}{l|l|l} 
A30 & 1555 & Icones avium. fol. (pdf e-rara) [woodcut of
\end{tabular} Gessner pdf p. 137]

A37 1555 De raris et admirandis herbis. Pilati Montis descriptio. 4to. (pdf e-rara)

\section{Froschauer}

Basel

Oporinus

Strasbourg

Wendelin

Rihel

Zurich: A.

Gessner +

Wyssenbch

Venice

Junta

Strasbourg

W. Rihel

Zurich

Froschauer

\section{Zurich}

Froschauer

Mar

Zurich

A J Gessner

Zurich

Froschauer

A J Gessner

Zurich

Froschauer

Zurich

Froschauer

Zurich

A J Gessner

Mithridates. 8vo. (pdf e-rara) [appended foldout table is absent in this copy; other

\section{Zurich Aug}

n.d.

Nicolaus Zurkinden, consiliarius. 2p.

Bern

Mar (pdf p. 610) Thomas Junta, printer. $1 / 2 p$

Venice

Mar

None; Gessner not involved

None; Gesnerus ad rei medicae studiosos

(pdf p. 610) Thomas Junta, printer. $1 / 2 p$

1. Lucius Kyber, pastor and father of deceased author. $8 p$

2. (pdf p. 624) Nicolaus Speicher, pharmacopola and friend of deceased. 1p.

Aug Thomas and Johannes Grey, brothers of Henry Duke of Suffolk. 1p

1. Valentinus Gravius, decimarius and senator from Fribourg. $1 \frac{1}{2} \mathrm{p}$

2. (pdf p. 126) Johannes Steiger, senator from Bern and quaestor for Savoy. $1 / 2 \mathrm{p}$

Achille Gasser, medicus. 3p.

Strasbourg

Strasbourg

England

Fribourg,

Switzerland

Bern

Augsburg

Johann Jakob Fugger, wealthy merchant. 31/2p

Augsburg

Geryonis [Gereon] Seiler, medicus of the city of Augsburg. Augsburg

$1 \frac{1}{2 p}$

Mar Caspar von Niedbruck [Nyderbruck or Nydbruck], noble

Vienna

counselor to Ferdinand and Maximilian. 3p

\begin{tabular}{l|l|l} 
Mar Ulrich Fugger, count of Kirchberg and Weissenhorn. 1p Augsburg
\end{tabular}

July

1. Laurentius Gryllus, medicus, bearing greeting to Ulrich

Landshut Fugger. 1p

2. (pdf p. 51) Johann Chrysostom Huober [Huber], Luzern medicus. $1 \mathrm{p}$

1. Johannes Bale, Englishman, bishop of Ossory, Ireland Ireland (spent time in Zurich). 11/2p 
digitizations also omit the table]

appended folded table not present in pdf

not in 1555 Otho Werdmüller, Similitudinum ab omni

Wellis animalium genere, in Johannes Fabricius

\begin{tabular}{|c|c|c|c|}
\hline & Sept & 2. Leonhard Beck von Beckenstein. $1 / 4 p$ & Augsburg \\
\hline $\begin{array}{l}\text { Zurich } \\
\text { A J Gessner }\end{array}$ & March & $\begin{array}{l}\text { Abel Werdmüller, adolescent son of Otho who died in } \\
\text { 1552; a relative of Gessner's }\end{array}$ & Zurich \\
\hline $\begin{array}{l}\text { Zurich } \\
\text { A J Gessner }\end{array}$ & Jan & $\begin{array}{l}\text { Johannes Wegmann and Felix Peierus [Peier], senators } \\
\text { and tribunes of Zurich. } 2 \mathrm{p} .\end{array}$ & Zurich \\
\hline \multirow[t]{4}{*}{$\begin{array}{l}\text { Zurich } \\
\text { A Gessner }\end{array}$} & n.d. & $\begin{array}{l}\text { 1. (pdf p. 11) Joan. Perrinus, learned young man, who } \\
\text { dedicated the book to Sebastian a Loys. } 1 \text { p }\end{array}$ & Lausanne \\
\hline & Mar & $\begin{array}{l}\text { 2. (pdf p. 23) Johannes Caius, medicus et philosophus. } \\
2 \frac{1}{2} p\end{array}$ & England \\
\hline & Apr & $\begin{array}{l}\text { 3. (pdf p. 105) Burchardus Mythobius, medicus et } \\
\text { philosophus. } 2 \frac{1}{2} p\end{array}$ & $\begin{array}{l}\text { Northern } \\
\text { Germany }\end{array}$ \\
\hline & June & 4. (pdf p. 256) Melchior Guilandus [Wieland]. 3p & Prussia \\
\hline $\begin{array}{l}\text { Zurich } \\
\text { A J Gessner }\end{array}$ & $\begin{array}{l}\text { Maythis } \\
\text { belongs } \\
\begin{array}{l}\text { above } \\
\text { the } \\
\text { previous }\end{array}\end{array}$ & $\begin{array}{l}\text { Johannes Jacobus Fugger, dominus of Kirchberg and } \\
\text { Weissenhorn, and Maecenas. } 2 p\end{array}$ & Augsburg \\
\hline $\begin{array}{l}\text { [Geneva] } \\
\text { H. Estienne }\end{array}$ & Feb & $\begin{array}{l}\text { (pdf p. 84, following Greek section which has no } \\
\text { dedication) Heinrich Bullinger. } 2 p . \\
\text { (in } 1559 \text { repr. same dedication on pdf p. 246) }\end{array}$ & Zurich \\
\hline $\begin{array}{l}\text { Padua } \\
\text { Perchacinus }\end{array}$ & & $\begin{array}{l}\text { None--Gessner not involved in the publication (comprises } \\
\text { one letter by Guilandinus and one by Gessner) }\end{array}$ & \\
\hline $\begin{array}{l}\text { Zurich } \\
\text { Froschauer }\end{array}$ & Aug & Ferdinand I, Holy Roman Emperor. 71/2p & Vienna \\
\hline $\begin{array}{l}\text { Zurich } \\
\text { A Gessner }\end{array}$ & Feb & $\begin{array}{l}\text { (pdf p. 292) (following Latin translation) Anton Werther } \\
\text { [von Werthern] von Beichlingen. In Greek. } 9 \frac{1}{2} p\end{array}$ & Beichlingen \\
\hline $\begin{array}{l}\text { Zurich } \\
\text { A Gessner }\end{array}$ & Feb & $\begin{array}{l}\text { (pdf p. 566) Joan. Du Choul, royal senator and prefect of } \\
\text { the Allobroges. } 2 p\end{array}$ & $\begin{array}{l}\text { Allobroges } \\
=\text { Dauphiné }\end{array}$ \\
\hline $\begin{array}{l}\text { Zurich } \\
\text { unspec. }\end{array}$ & Oct & Joan. Echtius [Backofen von Echt]. 11/2p & Cologne \\
\hline $\begin{array}{l}\text { Zurich } \\
\text { Froschauer }\end{array}$ & June & $\begin{array}{l}\text { 1. Elizabeth I, recently crowned queen of England. } 4 p+28- \\
\text { line Greek ode. }\end{array}$ & England \\
\hline & & 2. (pdf p. 144) Thomas and Johannes Grey (repeated from & \\
\hline
\end{tabular}

Montanus, Differentiae animalium

quadrupedum (pdf E-rara, pp. 137-376)

A41 1556 Sanitatis tuendae praecepta. 8vo. (pdf e-rara)

1556 De piscibus et aquatilibus omnibus libelli. 8vo

(pdf e-rara)

Catalogus aquatilium ex Plinio

Aquatilium ... nomina Germanica et Anglica

De fictis in Germanica lingua aquatilium nominibus

1556 Aelianus. Opera. fol. (e-rara, Gessner's own copy with annotations)

Zurich

Johannes Jacobus Fugger, dominus of Kirchberg and

Augsburg

\section{the}

A44. 2

Athenagoras. fol. (e-rara)

reprinted in 1559 Theologorum (Zurich: A

Gessner). fol. (pdf e-rara)

A45 1557 De stirpium aliquot epistolae. 8vo. (BnF, Google Books)

A26 1558 Historia animalium IV: De piscium...natura. fol. 8-year imp priv + 10-year F priv (pdf erara)

1559 Marcus Aurelius Antoninus. De vita sua. 8vo. 3 year priv unspec. (pdf e-rara)

Hannonis Carthaginensium ducis navigatio (in Leonis Africani de totius Africae descriptio) 16mo. (pdf e-rara)

A48.1 1559 Xenocrates de alimento ex aquatilibus. 8vo. (in lani Dubravii De piscinis) (pdf e-rara)

A29.2 1560 Icones Animalium (2nd ed.) fol. imp and French priv unspec. (pdf e-rara) [no woodcut]

2. (pdf p. 144) Thomas and Johannes Grey (repeated from

\footnotetext{
${ }^{3}$ I am grateful to Urs Leu for calling my attention to this dedication by Gessner in a work authored by another.
} 
Book II

Ordo II, tome II, on fresh water fish

accessio de Germanicis ... nominibus

Josua Maler. Dictionarium Germanicolatinum. 8vo. (partial pdf e-rara)

A51 1561 Valerius Cordus. Annotationes in Dioscorides, etc. fol. 8-year imp priv (pdf e-rara) Annotationes in Dioscoridis libros

Valerii Cordi historia plantarum

[extra plant pictures--no title] 8pp

Sylva observationum variarum (18pp)

De artificiosis extractionibus (9pp)

\section{Compositiones medicinales (5pp)}

Stocc-hornii ... montium descriptio (8pp) by

Benedictus Aretius, a friend of Gessner

Horti Germaniae

Appendix ... de hortis Germaniae

A52

1561

Historic

A54

1562

Cassius latrosophista. Naturales et

medicinales quaestiones. 8vo. (pdf e-rara)

Greek text
Claudius Galenus. fol. Opera omnia (mfilm

\begin{tabular}{|l|l|}
\hline Zurich & July \\
Froschauer & June \\
\hline & M Ju \\
\hline & Ju \\
\hline Zurich & \\
\hline Froschauer & \\
\hline Strasbourg & Ju \\
losias Rihel & \\
\hline & Aug \\
\hline
\end{tabular}

July

June

2. (pdf p. 130) Johannes Parkhurst, bishop of Norwich; former Marian exile in Zurich. 1p

1. Maximilian II, King of Bohemia and of Austria. 31/2p

Norwich,

England

Vienna

May

2. (pdf p. 309) Senate of Basel. 11/2p

Basel

June 3. (pdf p. 368) Sigismund, Freiherr von Herberstein, Nyperg and Guttenhag [imperial diplomat]. 1p

June $\quad$ 4. (pdf p. 400) Levinus Lemnius, medicus. $1 / 2 p$ None; Gessner ad lectorem praefatio

June $\quad$ 1. Faculty of Medicine, Wittenberg. $2 \frac{1}{2} p$

Aug 2. (pdf p. 11) Son of Joannis Ralla, recently deceased pharmacopola, who transmitted ms to Placotomus. 11/2p

Dec 1559 3. (pdf p. 190) Hieronymus Herold, medicus, proposed dedication \#1, supplied legible copy of $m s .2 p$

Jan 1560 4. (pdf p. 448) Caspar Collinus [Ambühl], pharmacopaeus. $1 / 4 \mathrm{p}$

Dec 1559 5. (pdf p. 456) Joannes Placotomus, medicus, sent $\mathrm{ms}$ to Gessner. $1 p$

Dec 1560 6. (pdf p. 472) Phillippus Bechius [Bächi], medicus, sent ms to Gessner. $1 p$

Dec 1560 7. (pdf p. 481) Sebald Hawenreuter [Hauenreuter], medicus. $1 / 2 p$

Jan 1560 8. (pdf p. 486) dedication by Gessner to Christophorus Piperinus [Pfäfferlin], minister. $1 / 2 p$

Jan 1560 9. (pdf p. 494) Stephanus Lauraeus, imperial medicus. 1p

Jun 1561 10. (pdf p. 598) Franciscus Calceolarius, pharmacopola. 2p None; published under a pseudonym (Conrad Bolovesus)

[Zurich]

[Zurich]

J Gessner

Jan

1. Johannes Kentmann, medicus. 4p

Jan / Feb 2. (pdf p. 70) in Greek: Antonios Niphoreios [Schneeberger] 31/2p

Basel

Basil Amerbach and the other professors of the Academy
Torgau in

Vienna etc

Zierikzee NL

Wittenberg

Leipzig

Nurnberg

from Leipzig

Sion, Switz.

Danzig

Basel

Strasbourg

Sigriswil,

Bern

Augsburg

Verona

Saxony

Cracow

From Zurich

Basel 


\begin{tabular}{|c|c|c|c|c|c|c|}
\hline & & Wellisch) & Froben & & of Basel. $4 p$ & \\
\hline A55 & 1562 & $\begin{array}{l}\text { Sante Arduino. De venenis. fol. imp priv } \\
\text { unspec (pdf BSB) }\end{array}$ & $\begin{array}{l}\text { Basel: } \\
\text { Henricpetri } \\
\text { \& Perna }\end{array}$ & & None; no mention of Gessner & \\
\hline A59 & 1563 & $\begin{array}{l}\text { Valerius Cordus. Stirpium descriptionis liber V. } \\
\text { fol (only 28p). 8-year imp priv (pdf BSB) }\end{array}$ & $\begin{array}{l}\text { Strasbourg } \\
\text { J Rihel }\end{array}$ & Aug 1562 & Wolfgang Meurer, medicus et philosophus. 1p. & Leipzig \\
\hline A56 & 1562 & $\begin{array}{l}\text { De libris a se editis epistola ad Guilielmum } \\
\text { Turnerum. } 8 \text { vo. (pdf e-rara) }\end{array}$ & $\begin{array}{l}\text { Zurich } \\
\text { Froschauer }\end{array}$ & Sept & William Turner. 1p. & England \\
\hline A57 & 1563 & $\begin{array}{l}\text { De anima liber. in Ioh. Lod. Vives, De anima et } \\
\text { vita. } 8 \text { vo. (pdf BSB) }\end{array}$ & $\begin{array}{l}\text { Zurich } \\
\text { J Gessner }\end{array}$ & Feb & $\begin{array}{l}\text { (pdf p. 1018) Julius Alexandrinus Tridentinus, medicus to } \\
\text { the emperor. } 3 p\end{array}$ & Vienna \\
\hline A58 & 1563 & $\begin{array}{l}\text { Jodocus Willich. Ars magirica. 8vo. (pdf e- } \\
\text { rara) }\end{array}$ & $\begin{array}{l}\text { Zurich } \\
\text { J Gessner }\end{array}$ & Aug & $\begin{array}{l}\text { Johannes Pontisella, "moderator Ludi," rector of the Latin } \\
\text { school. } 111 \frac{12 p .}{}\end{array}$ & $\begin{array}{l}\text { Chur, } \\
\text { Graubünden }\end{array}$ \\
\hline A60 & 1564 & $\begin{array}{l}\text { Henri Estienne. Dictionarium medicum. 8vo. } \\
\text { (pdf BSB) }\end{array}$ & $\begin{array}{l}\text { Geneva } \\
\text { H. Estienne }\end{array}$ & & $\begin{array}{l}\text { none by Gessner; dedication (inserted as a cancel) by } \mathrm{H} \text {. } \\
\text { Estienne to Philibertus Saracenus, medicus, } 2 \mathrm{p} .\end{array}$ & \\
\hline A61 & 1565 & $\begin{array}{l}\text { Dioscorides. De curationibus morborum. ed. } \\
\text { Joh. Moibanus and Gessner. fol. 8-year imp } \\
\text { priv (pdf Hathitrust) }\end{array}$ & $\begin{array}{l}\text { Strasbourg } \\
\text { J Rihel }\end{array}$ & $\begin{array}{l}\text { June } \\
1564\end{array}$ & $\begin{array}{l}\text { 1. Council and Senate of Augsburg. } 91 / 2 p \\
\text { 2. (pdf p. } 38 \text { ) in Greek. Joannis Crato [von Krafftheim]. } \\
61 / 2 p\end{array}$ & $\begin{array}{l}\text { 1. Augsburg } \\
\text { 2. Breslau }\end{array}$ \\
\hline \multirow[t]{5}{*}{ A63 } & 1565 & $\begin{array}{l}\text { De omni rerum fossilium genere. } 8 \mathrm{vo} \text {. (pdf } \\
\text { BSB complete) comprises } 10 \text { works by } 5 \\
\text { authors. only Gessner's listed here }\end{array}$ & $\begin{array}{l}\text { Zurich } \\
\text { J Gessner }\end{array}$ & & & \\
\hline & & De bitumine & & July & 1. (pdf p. 425) Valerando Dourez, pharmacopola. $2 p$ & Lyon \\
\hline & & Valerii Cordi de Halosantho & & & 2. (pdf p. 436) Andreae Pellizero, medicus. 21/2p & $\begin{array}{l}\text { Kärnten, } \\
\text { Austria }\end{array}$ \\
\hline & & Sancti Patris Epiphanii ... de XII gemmis & & July & 3. (pdf p. 514) Adolphus Occo, medicus. 31/2p & Augsburg \\
\hline & & De rerum fossilium, lapidum et gemmarum & & Aug & $\begin{array}{l}\text { 4. (pdf p.778) Andreas Schadcovius [Szadkowski], } \\
\text { notarius salinarum. } 7 p\end{array}$ & Cracow \\
\hline A62 & 1565 & $\begin{array}{l}\text { Jacques Houllier. Viaticum novum. 8vo. (pdf } \\
\text { e-rara) }\end{array}$ & $\begin{array}{l}\text { Zurich } \\
\text { Froschauer }\end{array}$ & & Gessner to the reader; dedication by Caspar Wolf & \\
\hline
\end{tabular}

